\title{
Modelling surface ozone during the 2003 heat-wave in the UK
}

\author{
M. Vieno ${ }^{1,2}$, A. J. Dore ${ }^{2}$, D. S. Stevenson ${ }^{1}$, R. Doherty ${ }^{1}$, M. R. Heal ${ }^{3}$, S. Reis ${ }^{2}$, S. Hallsworth ${ }^{2}$, L. Tarrason ${ }^{4}$, P. Wind ${ }^{5}$, \\ D. Fowler ${ }^{2}$, D. Simpson ${ }^{5,6}$, and M. A. Sutton ${ }^{2}$ \\ ${ }^{1}$ School of GeoSciences, The University of Edinburgh, UK \\ ${ }^{2}$ Centre for Ecology and Hydrology, Penicuik, UK \\ ${ }^{3}$ School of Chemistry, The University of Edinburgh, UK \\ ${ }^{4}$ Norwegian Institute for Air Research, Kjeller, Norway \\ ${ }^{5}$ Norwegian Meteorological Institute, Oslo, Norway \\ ${ }^{6}$ Dept. Earth \& Space Sciences, Chalmers University of Technology, Gothenburg, Sweden
}

Received: 15 July 2009 - Published in Atmos. Chem. Phys. Discuss.: 18 September 2009

Revised: 19 August 2010 - Accepted: 20 August 2010 - Published: 27 August 2010

\begin{abstract}
The EMEP4UK modelling system is a high resolution $\left(5 \times 5 \mathrm{~km}^{2}\right)$ application of the EMEP chemistrytransport model, designed for scientific and policy studies in the UK. We demonstrate the use and performance of the EMEP4UK system through the study of ground-level ozone $\left(\mathrm{O}_{3}\right)$ during the extreme August 2003 heat-wave. Meteorology is generated by the Weather Research and Forecast (WRF) model, nudged every six hours with reanalysis data. We focus on SE England, where hourly average $\mathrm{O}_{3}$ reached up to $140 \mathrm{ppb}$ during the heat-wave. EMEP4UK accurately reproduces elevated $\mathrm{O}_{3}$ and much of its day-to-day variability during the heat-wave. Key $\mathrm{O}_{3}$ precursors, nitrogen dioxide and isoprene, are less well simulated, but show generally accurate diurnal cycles and concentrations to within a factor of $\sim 2-3$ of observations. The modelled surface $\mathrm{O}_{3}$ distribution has an intricate spatio-temporal structure, governed by a combination of meteorology, emissions and photochemistry. A series of sensitivity runs with the model are used to explore the factors that influenced $\mathrm{O}_{3}$ levels during the heat-wave. Various factors appear to be important on different days and at different sites. Ozone imported from outside the model domain, especially the south, is very important on several days during the heat-wave, contributing up to $85 \mathrm{ppb}$. The effect of dry deposition is also important on several days. Modelled isoprene concentrations are generally best simulated if isoprene emissions are changed from the base emissions: typically doubled, but elevated by up to a factor of five on one hot
\end{abstract}

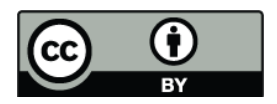

Correspondence to: M. Vieno (vieno.massimo@gmail.com) day. We found that accurate modelling of the exact positions of nitrogen oxide and volatile organic compound plumes is crucial for the successful simulation of $\mathrm{O}_{3}$ at a particular time and location. Variations in temperature of $\pm 5 \mathrm{~K}$ were found to have impacts on $\mathrm{O}_{3}$ of typically less than $\pm 10 \mathrm{ppb}$.

\section{Introduction}

In the UK, episodes of increased concentrations of groundlevel ozone often occur during periods of elevated temperatures associated with summertime anticyclonic conditions (e.g. Jenkin et al., 2002). During the first two weeks in August 2003, a blocking area of high atmospheric pressure centred over Scandinavia caused very high temperatures $\left(>35^{\circ} \mathrm{C}\right)$ for several consecutive days over parts of the UK and central Europe. This exceptional heat wave has been the focus of several studies (e.g., Schär and Jendritzky, 2004; Ordóñez et al., 2005; Trigo et al., 2005; Vautard et al., 2005; Solberg et al., 2008; Tressol et al., 2008; AndreaniAksoyoglu et al., 2008; Chaxel and Chollet, 2009). This event was associated with a series of afternoon ozone peaks, reaching above $90 \mathrm{ppb}$, in the south of England (Lee et al., 2006). The heat-wave period was coincident with the Tropospheric ORganic CHemisty (TORCH) field campaign (Lee et al., 2006), which provided detailed measurements of ozone concentrations and its precursors, including isoprene, at a site in Writtle about $70 \mathrm{~km} \mathrm{NE}$ of London. The high temperatures and high levels of ozone experienced during the 2003 heat-wave had a substantial effect on human health (Stedman, 2004). For our work, we assumed that the beginning

Published by Copernicus Publications on behalf of the European Geosciences Union. 
of the heat-wave was on the 4 August and the end was on the 12 August. Between these dates, observed and simulated daily maximum temperatures satisfied the UK Climate Impacts Programme (UKCIP) definition for a heat-wave. These dates match closely the 5-11 August period defined as heatwave in the work of Lee et al. (2006).

In this study we investigate the causes of the elevated ozone levels using a high resolution $\left(5 \times 5 \mathrm{~km}^{2}\right.$ grid $)$ chemical transport model system over the UK domain (EMEP4UK). This system comprises the EMEP chemical transport model (Simpson et al., 2003a), the Weather Research and Forecast model, and fine-scale UK emissions from UK national databases. This paper represents the first demonstration of the abilities of the EMEP4UK model for photochemical oxidant modelling in the UK. We first show that the model system is able to simulate hourly ozone measurements realistically from a range of sites over SE England during 2003, including measurements made as part of the TORCH campaign. We then conduct a series of sensitivity runs to investigate the influences of a variety of different meteorological and chemical factors (temperature, anthropogenic volatile organic compounds, emissions of biogenic isoprene, anthropogenic emissions of $\mathrm{NO}_{\mathrm{x}}\left(\mathrm{NO}+\mathrm{NO}_{2}\right)$, ozone dry deposition, and transport) that contributed to the high ozone episodes in this region during the August 2003 heat-wave.

\section{Model description and set-up}

The EMEP4UK model framework is a nested regional chemistry-transport model (CTM) driven by high-resolution meteorology and national emissions that is used to produce a detailed representation of the physical and chemical state of the atmosphere over Europe and, in particular, over the UK (Vieno et al., 2009). The underlying CTM is the EMEP Unified Model (Simpson et al., 2003a), which has been modified in recent years to enable application on spatial scales ranging from the $5 \times 5 \mathrm{~km}^{2}$ grid used here for the UK to the global scale (Jonson et al. 2007, 2010).

For this study, the EMEP4UK model was driven by the Weather Research Forecast (WRF) model (www.wrfmodel.org) with a resolution of $5 \times 5 \mathrm{~km}^{2}$. The WRF model included data assimilation (Newtonian nudging) of the numerical weather prediction (NWP) model meteorological reanalysis from the US National Center for Environmental Prediction (NCEP)/National Center for Atmospheric Research (NCAR) Global Forecast System (GFS) at $1^{\circ}$ resolution, every $6 \mathrm{~h}$.

The WRF/EMEP4UK model was applied here using a one-way nested domain approach, with an outer domain resolution of $50 \times 50 \mathrm{~km}^{2}$ covering the official EMEP domain (Simpson et al., 2003a), an intermediate domain resolution of $10 \times 10 \mathrm{~km}^{2}$ and an inner domain with a resolution of $5 \times 5 \mathrm{~km}^{2}$. Simulations were performed over each of these domains, the results from the outermost domain being used as boundary conditions to the intermediate domain and so on. The intermediate domain is required by the WRF model due to the complexity of simulating atmospheric dynamics, with stability criteria imposing a maximum nesting factor of 5 . For the chemical transport (EMEP) modelling there are fewer numerical restrictions and we make use of just the outer and inner domains. As the inner domain covers all of the UK, this approach simplifies the interpretation of the model tests.

The innermost domain covers the whole British Isles, plus adjacent parts of France, Denmark, Holland and Belgium. Both WRF and EMEP4UK models use 20 vertical layers, with terrain following coordinates, and resolution increasing towards the surface. The vertical column extends from the surface (centre of the surface layer $\sim 45 \mathrm{~m}$ ) up to $100 \mathrm{hPa}$ $(\sim 16 \mathrm{~km})$. Modelled species are calculated at $3 \mathrm{~m}$ above the surface plant or other canopy by making use of the constant-flux assumption and definition of aerodynamic resistance (Simpson et al., 2003b). The WRF coarse grid of $50 \times 50 \mathrm{~km}^{2}$ resolution was used to drive the EMEP model across the European domain to calculate the chemical initial conditions and boundary conditions (one-way nesting approach) for the EMEP4UK model (driven by the inner WRF domain $\left.5 \times 5 \mathrm{~km}^{2}\right)$. The EMEP model itself $\left(50 \times 50 \mathrm{~km}^{2}\right)$ was initialised with climatologically-derived ozone boundary and initial conditions (Logan, 1999). To simulate the import of ozone realistically in a specific year, the so called "Mace Head" adjustment was applied (Simpson et al., 2003a). This adjustment uses monthly "clean-air (Atlantic)" observations from the Mace Head site on the west coast of Ireland, adjusting the monthly Logan climatology to match Mace Head data, and it was only applied to the EMEP Unified Model at $50 \times 50 \mathrm{~km}^{2}$ resolution.

The current EMEP Unified model is a development of the 3-D chemical transport model of Berge and Jakobsen (1998), extended with photo-oxidant chemistry (Simpson et al., 1995, 2003a; Andersson-Sköld et al., 1999) and the EQSAM gas/aerosol partitioning model (Metzger et al., 2002). Two types of emissions are present in the model: anthropogenic and natural. For the UK, anthropogenic emissions of $\mathrm{NO}_{\mathrm{x}}, \mathrm{NH}_{3}, \mathrm{SO}_{2}, \mathrm{PM}_{2.5}, \mathrm{PM}_{C O}$ (coarse particulate matter), $\mathrm{CO}$, and non-methane VOC (NMVOC) are integrated from the UK National Atmospheric Emissions Inventories (NAEI) $1 \times 1 \mathrm{~km}^{2}$ emissions to the required $5 \times 5 \mathrm{~km}^{2}$ (Dore et al., 2008; Hellsten et al., 2008). Elsewhere and for international shipping, EMEP $50 \times 50 \mathrm{~km}^{2}$ emissions are used (www.emep.int). NMVOC are speciated into 10 reactive and one unreactive species, using emission-sector specific values as shown in Simpson et al. (2003a). Biogenic emissions of isoprene are based on Guenther et al. (1993) and Simpson et al. (1999), driven by EMEP $50 \times 50 \mathrm{~km}^{2}$ landuse, temperature and light. Emissions of monoterpenes are not included in this version of the model; this is discussed in Sect. 4.2.3. Biogenic emissions of dimethlysulphide (DMS) are input as monthly average emission data, derived from Tarrason et al. (1995), and treated as $\mathrm{SO}_{2}$ on input to the 
calculations. Emissions of $\mathrm{NO}_{\mathrm{x}}$ from lightning are included as monthly averages (Köhler et al., 1995). Seasonally averaged aircraft emissions are included for $\mathrm{NO}_{\mathrm{x}}$ from Gardner et al. (1997). Both aircraft and lightning emissions are provided as 3-D fields for the whole model domain. Natural soil $\mathrm{NO}_{\mathrm{x}}$ emissions and non-anthropogenic biomass burning are not included. For $\mathrm{CH}_{4}$ a constant mixing ratio over the whole domain is prescribed (Simpson et al., 2003a).

Sixteen basic land-use classes are used in the dry deposition module of the EMEP4UK model. For those vegetative landuse categories for which stomatal modelling is undertaken, the start and end of the growing season is specified and the development of leaf area index within this growing season is also modelled (Simpson et al., 2003a, b). Dry deposition is calculated using a resistance analogy combined with stomatal and non-stomatal conductance algorithms (Emberson et al., 2001; Simpson et al., 2003a, b), whereas wet deposition uses scavenging coefficients applied to the 3-D rainfall.

Full details of the EMEP model are given in Simpson et al. (2003a) and Fagerli et al. (2004).

\section{Methods}

A full year simulation was performed for 2003 using EMEP4UK/WRF in the configuration described in Sect. 2. Thirteen further one-month sensitivity experiments were carried out to investigate the contributing factors to the elevated ozone in the southern UK during the 2003 August heat-wave. These were identical to the base experiment in all respects except that in each case a single meteorological or chemical variable was changed in the EMEP4UK $5 \times 5 \mathrm{~km}^{2}$ grid inner domain. Use of a one-way nesting algorithm means that changes to fields within the inner domain do not influence fields in the outer domains. With this set-up, any air that recirculates (i.e. exits the inner domain, then re-enters) will lose the original influence of the inner domain also the coarse domain used to calculate the boundary and initial condition was not modified. This approximation is not expected to lead to significant problems in the simulations reported here.

The first factor investigated was surface temperature, which was either increased or decreased by $5 \mathrm{~K}$. This affected ozone by changing both emissions of biogenic isoprene, and dry deposition of ozone through the surface exchange scheme. The 3-D potential temperature has also been increased by $+5 \mathrm{~K}$ and $+10 \mathrm{~K}$, to investigate the effect of temperature on the chemistry. The imposed change in temperature did not affect the dynamic meteorology, as the influence was limited to the chemical transport (EMEP) part of the code, and no feedbacks operate from the EMEP model to WRF. Furthermore, those dispersion parameters which are calculated in the EMEP model (mixing height, eddy diffusivity) rely on gradients in potential temperature rather than absolute temperature. As these gradients are preserved with a uniform 5 or $10 \mathrm{~K}$ change in potential temperature, this test only affects the chemical scheme and avoids unphysical (and NWP inconsistent) effects on the EMEP dispersion rates. Several experiments then varied emissions of specific species: biogenic isoprene (zero (no emissions), $2 \times$, and $5 \times$ base case emissions), anthropogenic VOC $( \pm 50 \%)$, or anthropogenic $\mathrm{NO}_{\mathrm{x}}(-10 \%$ and $-50 \%)$. The focus of the three isoprene experiments, generally the most important biogenic VOC with regard to ozone formation, was to investigate the importance of UK-generated isoprene on surface ozone formation. As an extreme test of the importance of dry deposition, a further experiment was conducted in which ozone dry deposition (both stomatal and non-stomatal) was entirely switched off. The final experiment fixed ozone at the EMEP4UK boundary to the monthly climatological value from Logan (1999) rather than using 3-hourly values from the EMEP $50 \times 50 \mathrm{~km}^{2}$ model. Hereafter we refer to this as the " $\mathrm{O}_{3}$ import" experiment. This allowed the influence of import from the outer domain to be isolated. The sensitivity experiments are summarised in Table 1.

\section{Results and discussion}

\subsection{Base 2003 simulation}

\subsubsection{Surface temperature}

To demonstrate that surface temperatures simulated by WRF with data assimilation produce a realistic representation of the August 2003 heat-wave, we compare model output with independent measurements (i.e., data that were not used in the WRF assimilation) during the TORCH campaign. Figure 1a shows hourly surface temperatures calculated by WRF from the $5 \times \mathrm{km}^{2}$ grid cell containing Writtle $\left(51^{\circ} 44^{\prime} 12^{\prime \prime} \mathrm{N}\right.$, $0^{\circ} 25^{\prime} 28^{\prime \prime} \mathrm{E}$ ), together with data from two instruments deployed during the TORCH campaign. Figure $1 b$ shows a similar comparison for observed versus modelled temperature at a nearby UK Met Office weather station in Wattisham $\left(52^{\circ} 07^{\prime} 22^{\prime \prime} \mathrm{N}, 0^{\circ} 57^{\prime} 43^{\prime \prime} \mathrm{E}\right)$. WRF is able to simulate the diurnal and longer timescale variations of temperature. August hourly temperatures during the heat-wave are generally well simulated (Fig. 1a compared to the Univ. Leicester sensor: $R^{2}=0.9$, slope 0.9 intercept of $0.7 \mathrm{~K}$; Univ. Leeds sensor: $R^{2}=0.9$, slope 0.8 and intercept of $0.6 \mathrm{~K}$, Fig. $1 \mathrm{~b}, R^{2}=0.8$, slope 0.9 , intercept $0.8 \mathrm{~K}$ ). However, the model underestimates some peak temperatures (by up to $5 \mathrm{~K}$ ), particularly in the period of 9-11 August. Possible reasons for this discrepancy might include: (a) limitations in the driving analysis and assimilated data, (b) significant sub-grid variation that the model cannot resolve i.e., for scales less than $5 \mathrm{~km}$ in the horizontal or less than $90 \mathrm{~m}$ in the vertical, or (c) that the landuse input to the model, and WRF's handling of this, does not perfectly reproduce the local area. This latter factor could lead to an erroneous calculation of surface temperature, especially in cases where stagnating air is present 
Table 1. Summary of the maximum changes in model-simulated ozone at the Writtle site during the first 15 days August 2003 induced by each of the various sensitivity model experiments described in this work.

\begin{tabular}{llrrl}
\hline & Sensitivity test & $+(\mathrm{ppb})$ & $-(\mathrm{ppb})$ & Effect on \\
\hline 1 & $+5 \mathrm{~K}$ Temperature $(2 \mathrm{~m})$ & 9 & 0 & Biogenic emission and dry dep. \\
2 & $-5 \mathrm{~K}$ Temperature $(2 \mathrm{~m})$ & 0 & 9 & Biogenic emission and dry dep. \\
3 & $+5 \mathrm{~K}$ 3-D potential temperature & 10 & 0 & Chemistry \\
4 & $+10 \mathrm{~K}$ 3-D potential temperature & 15 & 0 & Chemistry \\
5 & +50\% UK NMVOC emissions & 30 & 0 & Chemistry \\
6 & -50\% UK NMVOC emissions & 0 & 16 & Chemistry \\
7 & No Isoprene emissions & 0 & 10 & Chemistry \\
8 & 2× UK Isoprene emissions & 10 & 0 & Chemistry \\
9 & $5 \times$ UK isoprene emissions & 45 & 0 & Chemistry \\
10 & -50\% UK NO $\mathrm{x}_{\mathrm{x}}$ emissions & 65 & 5 & Chemistry \\
11 & $-10 \%$ UK NO \\
x emissions & 9 & 1 & Chemistry \\
12 & No dry deposition of $\mathrm{O}_{3}$ & 50 & 2 & Dry deposition \\
13 & fixed boundary conditions & 10 & 85 & All \\
\hline
\end{tabular}

and the heat island effect may be larger. The temperature sensors used may also have accuracy limitations. The fact that there is some disagreement between the two sensors at Writtle (TORCH) indicates that at least one of these introduces uncertainty of up to $3 \mathrm{~K}$. In summary, despite some limitations, the WRF model captures the main features of the heat-wave and diurnal variations of temperature during $\mathrm{Au}-$ gust 2003.

As an additional test of the WRF model performances we compared the calculated hourly temperature for the first 15 days of August 2003 at all available UK site of the UK Meteorological Office MIDAS Land Surface Station data (169 sites across the UK, data available from http://badc.nerc. ac.uk/data/ukmo-midas). Overall the bias was found to be $1.5^{\circ} \mathrm{C}$ as for the Wattisham site (Fig. 1b); hence the bias at Writtle site $\left(2^{\circ} \mathrm{C}\right)$ is larger than at other UK sites for the corresponding period.

\subsubsection{Surface wind speed and direction}

Wind speed and direction are also important parameters that may influence surface ozone at a given location. Figure 2 shows the comparison between the WRF model and observation for the first 15 days of August at Wattisham for surface wind speed and direction. The low winds speeds associated with the slow-moving anticyclone over Europe are well represented, although the magnitude of simulated low wind speeds is underestimated on average by $1.3 \mathrm{~m} \mathrm{~s}^{-1}$ $\left( \pm 1.2 \mathrm{~m} \mathrm{~s}^{-1}\right.$ one standard deviation). Moreover, the wind direction (generally from the south east or south west) is well captured by the model $\left(R^{2}=0.9\right.$, slope 0.8 and intercept of 18 degrees). We note that the highest wind speeds occur on the 6 August when imported ozone made the largest contribution to the ozone simulated at Writtle as compared to other days in the 15-day period (see Sect. 4.2.6). For the 9-10 August when wind speed are lowest the model suggests a smaller

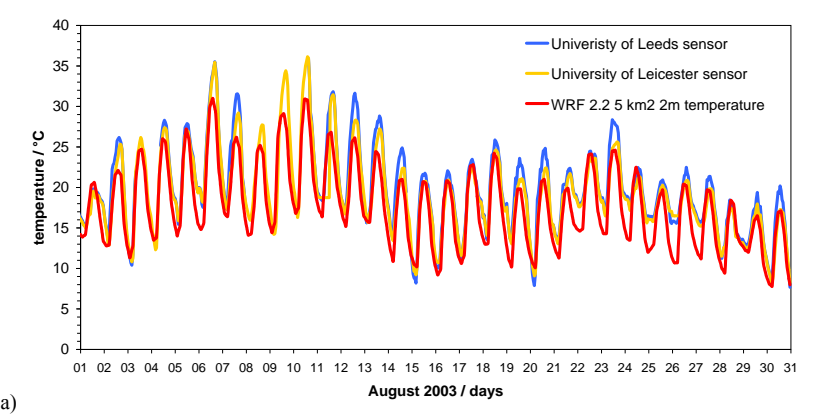

a)

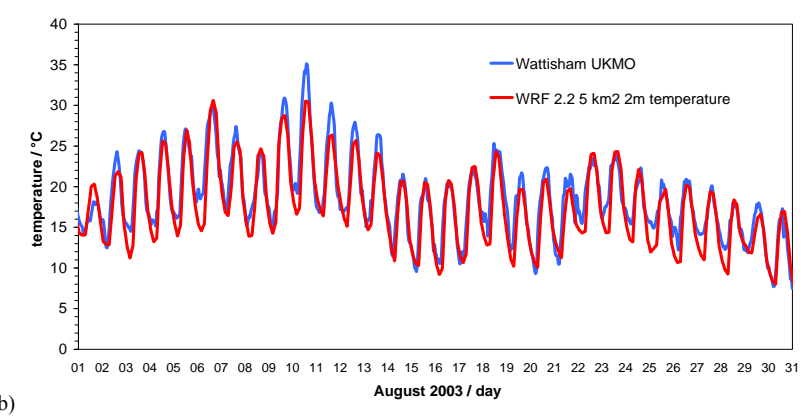

Fig. 1. Measured (blue, orange) and modelled (red) hourly surface temperature $\left({ }^{\circ} \mathrm{C}\right.$ ) during August 2003 at (a) Writtle TORCH campaign, and (b) Wattisham UK Met Office weather station. For Writtle, measurements from two different sensors are shown. Model results are from the WRF $5 \times 5 \mathrm{~km}^{2}$ grid-square containing the site.

easterly component of the wind than is observed (Fig. 2). An important point we note is that wind speeds on the 9-10 August were amongst the lowest of the period, and overall during the whole heat-wave period the wind speeds were low (Lee et al., 2006) as expected due to anticyclonic conditions. We expect considerable variability in wind direction with low wind speed. 


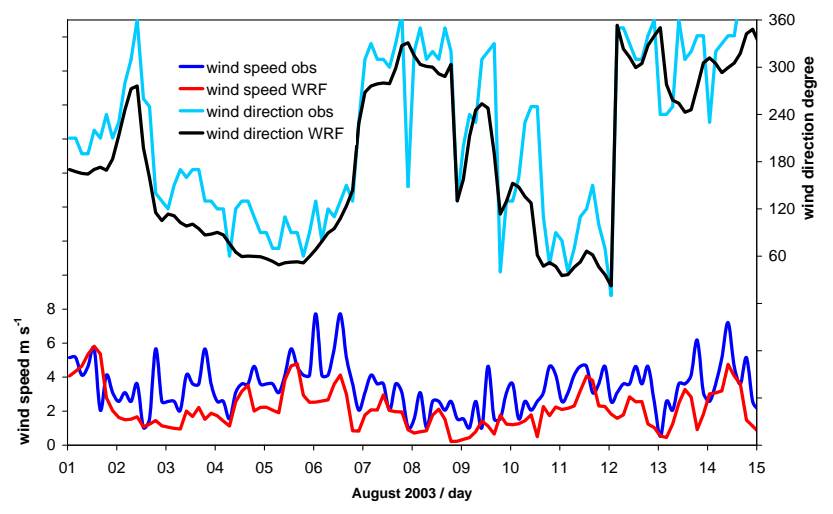

Fig. 2. Time series of hourly modelled (red, black) and observed (blue, pale blue) $10 \mathrm{~m}$ wind speed (bottom, $\mathrm{m} \mathrm{s}^{-1}$ ) and $10 \mathrm{~m}$ wind direction (top, degrees) at Wattisham.

\subsubsection{Surface ozone}

Figure $3 \mathrm{a}$ and $\mathrm{b}$ show observed and model-simulated surface ozone for two sites from the UK Automatic Urban and Rural monitoring network (AURN), for the hour 14:0015:00 GMT for each day of 2003. The two sites are Wicken Fen (for all hours of 2003, $R^{2}=0.6$, slope $=0.7$ and intercept $=12 \mathrm{ppb})$, a rural site $\left(52^{\circ} 17^{\prime} 54^{\prime \prime} \mathrm{N}, 0^{\circ} 17^{\prime} 28^{\prime \prime} \mathrm{E}\right)$, and London Eltham (for all hours of $2003, R^{2}=0.6$, slope $=0.8$ and intercept $=10 \mathrm{ppb})$, an urban background site $\left(51^{\circ} 27^{\prime} 09^{\prime \prime} \mathrm{N}\right.$, $0^{\circ} 04^{\prime} 14^{\prime \prime}$ ), (see Fig. 7 for locations). The model closely simulates the seasonal variation of surface ozone at the two sites. Moreover the model is able to capture ozone peaks ( $>50 \mathrm{ppb}$ ) for the whole of 2003. It is interesting to note that the August episode is not exceptional - there are several episodes of similar magnitude, from late March to midSeptember. The fact that comparatively high concentrations of ozone occur in England at other times not associated with exceptional temperatures is probably linked to the fact that many ozone episodes can be attributed to long-range transport, arising from precursors over continental Europe and with multi-day processes controlling ozone formation (e.g. Cox et al., 1975, Guicherit and van Dop, 1977; Simpson et al., 1995). We found that there is not a clear direct link between high UK temperature and high UK ozone, since high UK ozone episodes may occur at relatively low UK temperatures when ozone and/or precursors are imported from outside of the inner model domain.

Modelled and observed hourly ozone from the same two AURN stations (Wicken Fen and London Eltham) in August 2003 are shown in Fig. 4a and b. Similarly, model simulations are compared with observations at Writtle (TORCH) in Fig. 4c. Scatter plots of these data are shown in Fig. 5. In terms of $R^{2}$ for all the hourly August data, the model performs best at Wicken Fen $\left(R^{2}=0.7\right)$, London Eltham $\left(R^{2}=0.6\right)$ and worst at Writtle $\left(R^{2}=0.5\right)$. Nevertheless, the model accurately simulates many of the high ozone days dur-

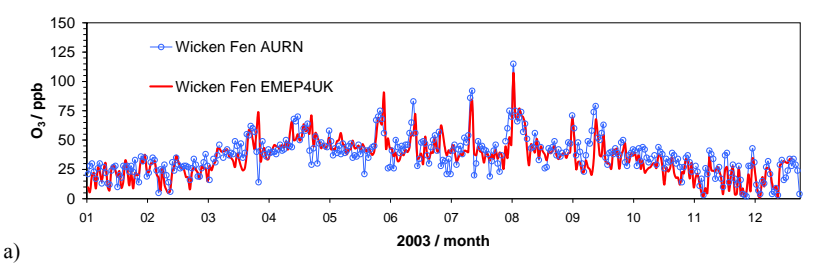

a)

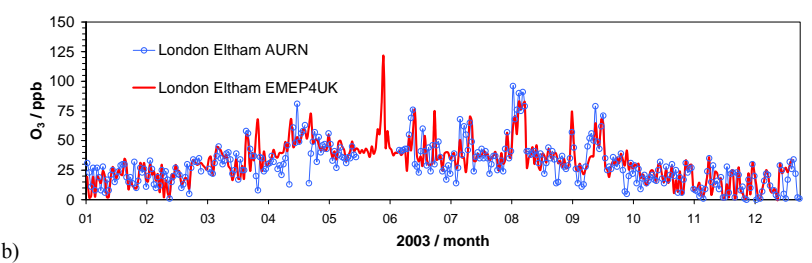

b)

Fig. 3. Mid-afternoon (14:00-15:00) hourly mean surface ozone (ppb) for each day of 2003 (modelled, red; measured, blue) at: (a) Wicken Fen and (b) London Eltham (some missing data in the observations in May and June).
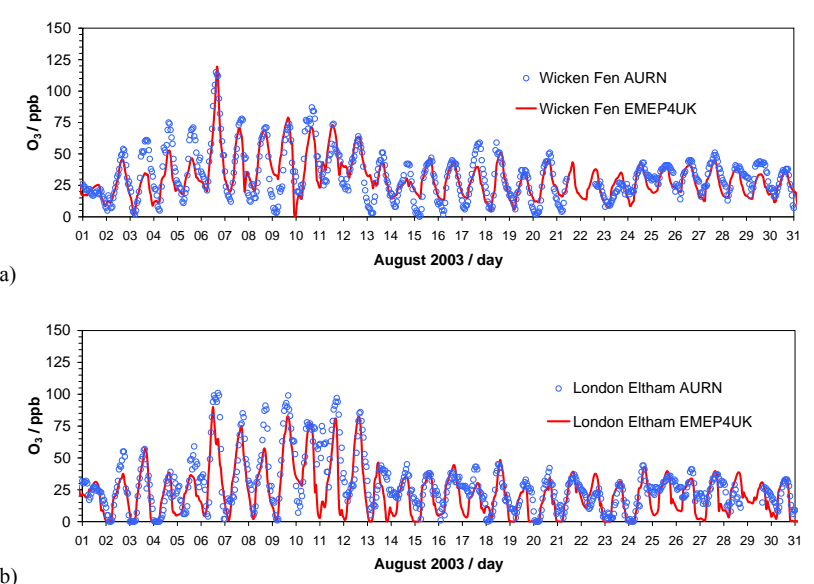

b)

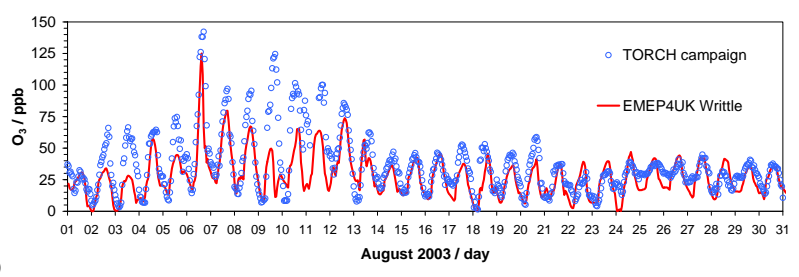

Fig. 4. Hourly time-series of modelled (red line) and measured (blue circles) surface ozone (ppb) during August 2003 at: (a) Wicken Fen, (b) London Eltham, and (c) TORCH campaign (Writtle).

ing the heat-wave in comparison to cooler days with lower ozone, and the typical diurnal variation of ozone at the three sites. At Writtle, the discrepancy between observed and simulated surface ozone is greatest between the 8-11 August. There are several potential meteorological drivers that may help to explain differences between observed and simulated surface ozone. Firstly, underestimated peak temperatures 

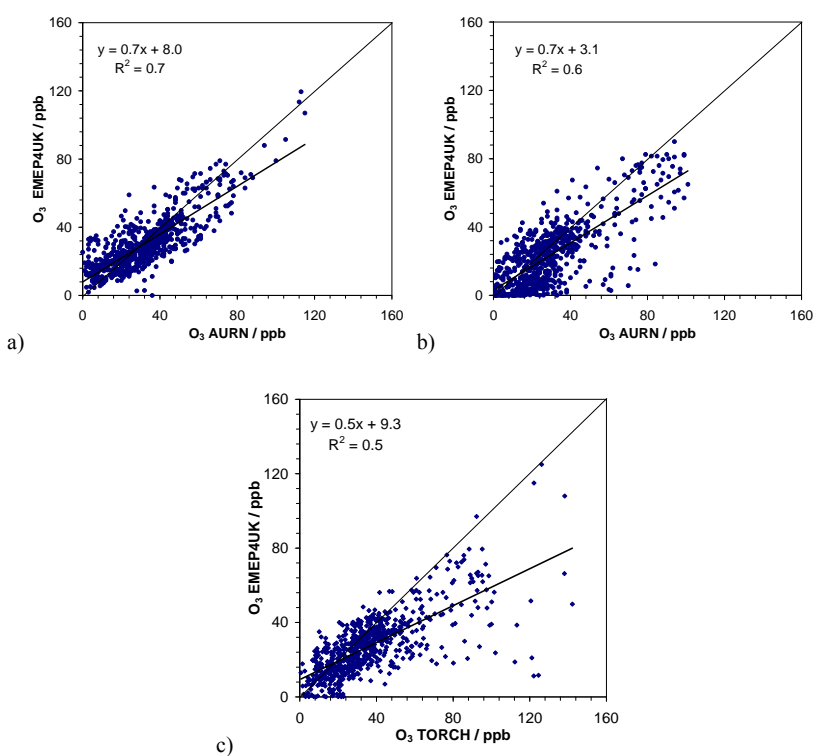

Fig. 5. Scatter plots of modelled vs. observed hourly August 2003 surface ozone (ppb) at (a) Wicken Fen (AURN), (b) London Eltham (AURN), and (c) Writtle (TORCH). The 1:1 line extends to the full scale whereas the best fit line finishes with the maximum modelled or observed value.

would yield lower isoprene emissions, which under high $\mathrm{NO}_{\mathrm{x}}$ conditions would mean less local ozone production. Lower temperatures would shift equilibrium towards more peroxyacetyl nitrate formation, tying up some $\mathrm{NO}_{\mathrm{x}}$ and radicals thus lowering local ozone production (Sillman and Samson, 1995; Baertsch-Ritter et al., 2004). Secondly, a lower frequency of easterly wind components on the 9-10 August could lead to lesser background concentrations of "high" ozone since the highest ozone concentrations during the heatwave period were found over France and Germany in both model and observations (not shown), although we note that winds were light. Further reasons for the discrepancy between the model and observations at Writtle are discussed in Sect. 4.2.

The spatial and temporal variability of simulated surface daily maximum ozone for the first 15 days of August 2003 is shown in Fig. 6. During this period a clear feature of elevated ozone building up after the 3 August is visible across southern England. The feature shows strong spatial and dayto-day variability. The detailed structure in the simulated $\mathrm{O}_{3}$ field clearly illustrates how difficult it is to simulate every site accurately, particularly those close to emissions sources or with other strong local influences on ozone.

The modelled monthly mean distribution of surface ozone for August 2003 is shown in Fig. 7, together with the location of the observation sites included in this study. The influence of surface $\mathrm{NO}_{\mathrm{x}}$ emissions on these ozone fields is clearly evident along road corridors and over cities such as London, Birmingham and Manchester. This highlights the importance

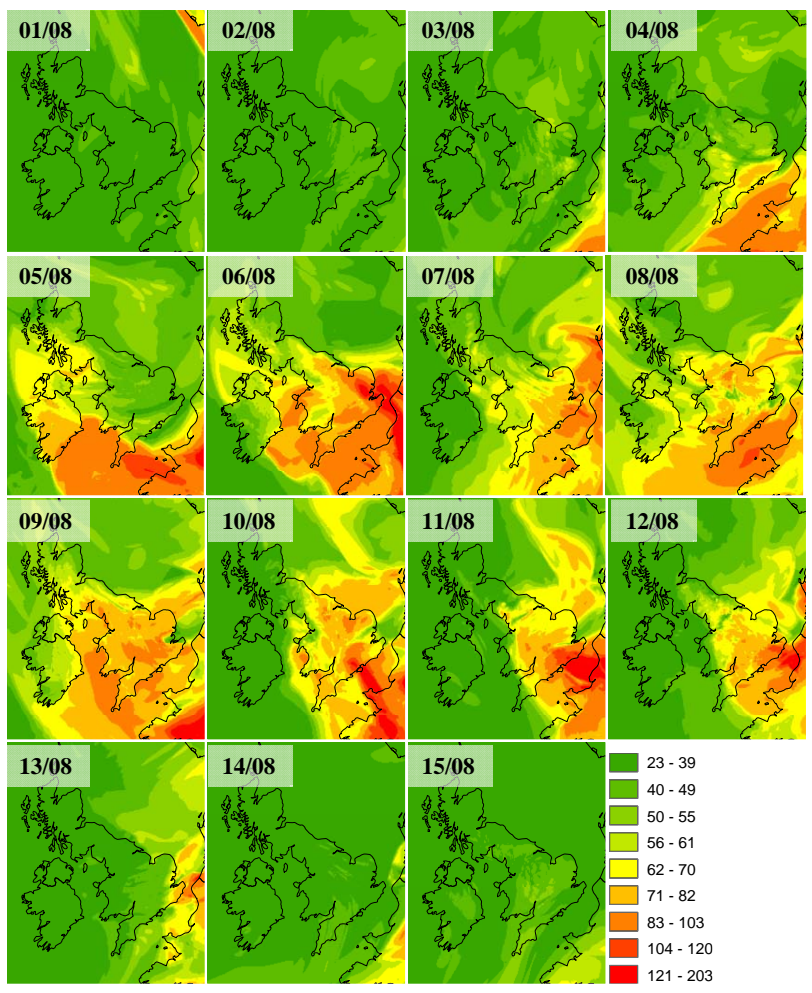

Fig. 6. EMEP4UK surface daily maximum ozone (ppb) for the first 15 days of August 2003.

of detailed emissions to simulate properly the spatial pattern of ozone over the UK and, more generally, wherever discrete emissions are present (i.e., road, point sources etc.).

\subsection{Which factors contributed to the high surface ozone during the 2003 heat-wave?}

In this section we present and discuss results from the sensitivity experiments described in Table 1, with the aim of determining the key factors that led to the high values of ozone during the 2003 heat-wave. We focus in particular on $\mathrm{O}_{3}$ at Writtle, but also consider the influences on $\mathrm{O}_{3}$ across the EMEP4UK model domain.

\subsubsection{Surface temperature and 3-D potential temperature}

Figure 8 shows the results of the temperature sensitivity experiments $( \pm 5 \mathrm{~K})$ on model-simulated surface ozone for the first 15 days in August 2003 at Writtle. Increasing and decreasing the surface temperature by $5 \mathrm{~K}$ increases and decreases surface ozone by approximately similar amounts, up to $9 \mathrm{ppb}$. Surface temperature affects isoprene emissions and dry deposition. A temperature increase of $5 \mathrm{~K}$ enhances the isoprene surface concentration in a similar way to the $2 \times$ isoprene experiment shown in Sect. 4.2.3, and in fact both experiments show similar results. The EMEP model isoprene 


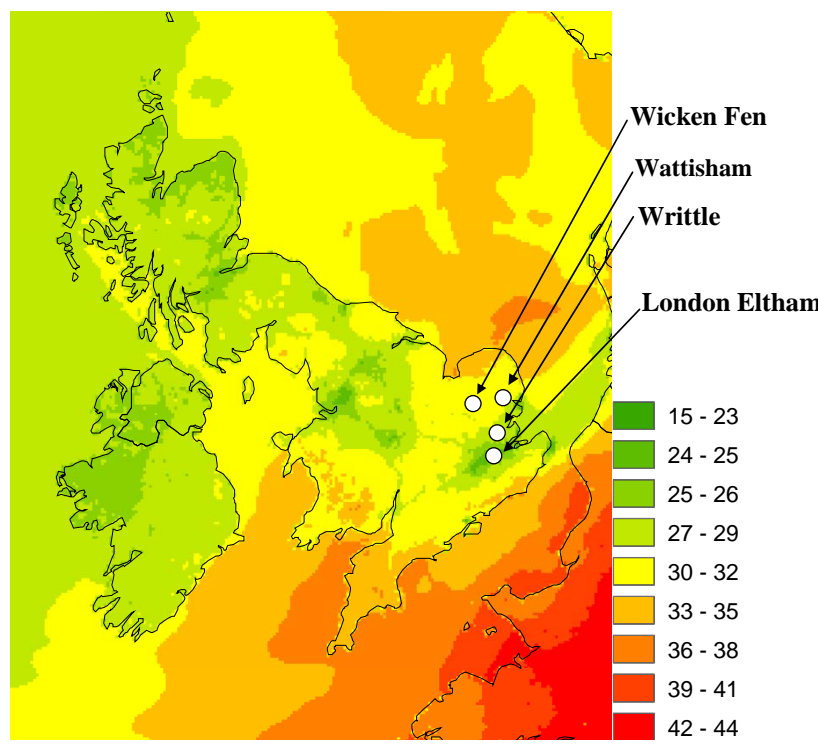

Fig. 7. Monthly mean (August 2003) surface ozone (ppb) calculated by the EMEP4UK model. The white dots indicate the sites included in this work.

emissions scheme is based on that of Guenther et al. (1995) and Simpson et al. (2003a). At $30^{\circ} \mathrm{C}$ (the average max temperature during the heat-wave period) a $5^{\circ} \mathrm{C}$ increase in temperature corresponds to a doubling of isoprene emissions. This similarity suggests that the major parameter modified by the temperature experiment in this range of temperatures is the isoprene emissions.

Over the 15-day period a $+5 \mathrm{~K}$ and $+10 \mathrm{~K}$ increase of the 3-D potential temperature monotonically increased surface $\mathrm{O}_{3}$ by up to 10 and $15 \mathrm{ppb}$, respectively. The results for the $+5 \mathrm{~K}$ increase of 3-D potential temperature are shown in Figure 8 (Changes in $\mathrm{O}_{3}$ for $10 \mathrm{~K}$, not shown, are essentially double those of the $5 \mathrm{~K}$ experiment). Considering that 5 or $10 \mathrm{~K}$ changes are a large perturbation to 3 -D temperature as compared with model biases, we suggest that $\mathrm{O}_{3}$ is biased only by a few ppb due to the effects of WRF model temperature biases on the EMEP model. The change of potential temperature throughout the atmosphere affects all chemical conversion rates only, whereas the effect of surface temperature change is limited to isoprene emission and dry deposition rates only. As mentioned in the methods section, the changes to 3-D temperature were applied only to the chemistry, leaving the dynamic meteorology unchanged.

\subsubsection{Anthropogenic NMVOC emissions}

The effects of the NMVOC sensitivity experiments on modelled surface ozone are shown in Fig. 9. When the UK anthropogenic emissions of NMVOC were modified by $\pm 50 \%$, the model response was to change surface ozone at Writtle by typically $\pm 4 \mathrm{ppb}$. Larger responses occurred on the 2,6 ,

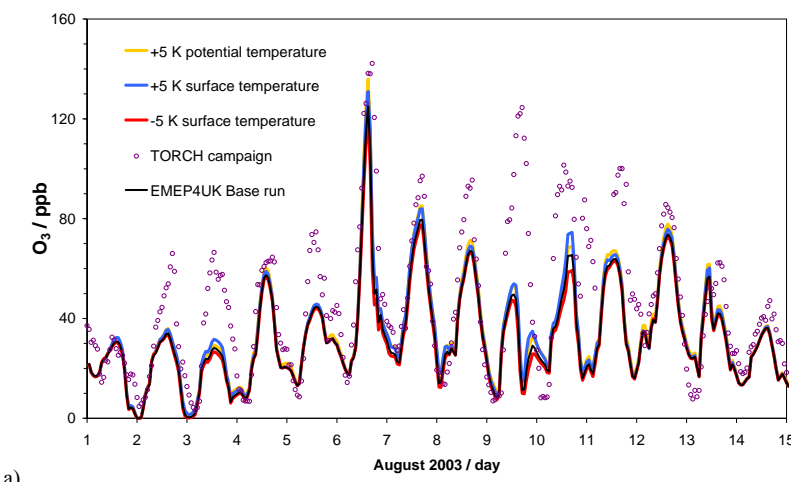

b)

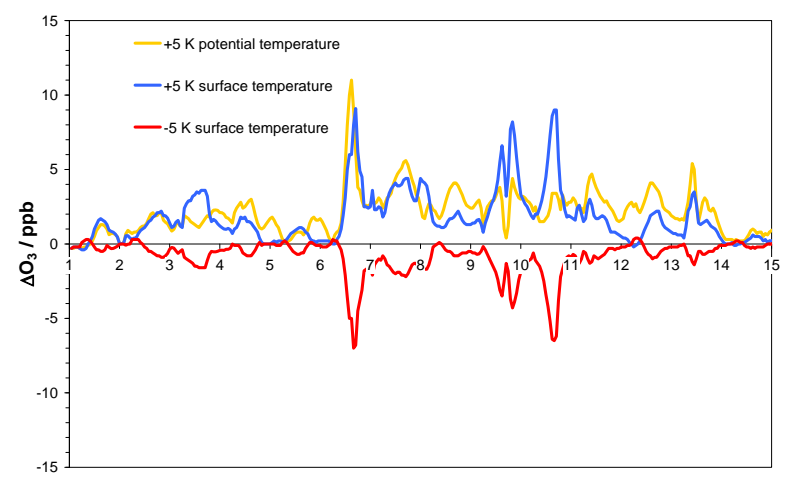

Fig. 8. (a) Hourly time-series of modelled (lines) and measured (circles) surface ozone (ppb) for 1-15 August 2003 at the TORCH campaign site, Writtle. EMEP4UK baseline simulation (black line) and model sensitivity experiments for 3 -D potential temperature $(+5 \mathrm{~K}$ yellow) and surface temperature $(+5 \mathrm{~K}$, blue; $-5 \mathrm{~K}$ red): (b) change in $\mathrm{O}_{3}$ (ppb) for the three sensitivity experiments relative to the baseline.

9 and 13 August, when an increase in NMVOC increased surface ozone by as much as $30 \mathrm{ppb}$, while reduced NMVOC emissions decreased it by as much as 16 ppb (Fig. 9). Some of the days showing great sensitivity $(6,9$ August) coincide with days when the temperature-induced changes were also important, but other days (2, 13 August) seem specific to NMVOC. As temperature changes in the model impact BVOC emissions but not anthropogenic VOC, these different periods likely reflect days when isoprene did and did not play a large role in ozone formation.

Sensitivity of ozone to NMVOC is a classic sign of high$\mathrm{NO}_{\mathrm{x}}$ chemistry (Sillman et al., 1990; Simpson et al., 1995) and indeed the model results for surface $\mathrm{NO}_{2}$ (see Sect. 4.2.4) show an abundance of $\mathrm{NO}_{2}$ on 2 and 9 August. For the 6 August the absolute difference of maximum surface ozone is $\sim 5 \mathrm{ppb}$ (Fig. 9a), but the timing of the peak is altered by perturbing emissions of NMVOC by $\pm 50 \%$. Surface ozone decrease is limited to $16 \mathrm{ppb}$ when the NMVOC emissions have been reduced by half. The implication is that a possible UK policy aiming to decrease ozone by controlling NMVOC emissions will have non-linear and limited effects, and in 


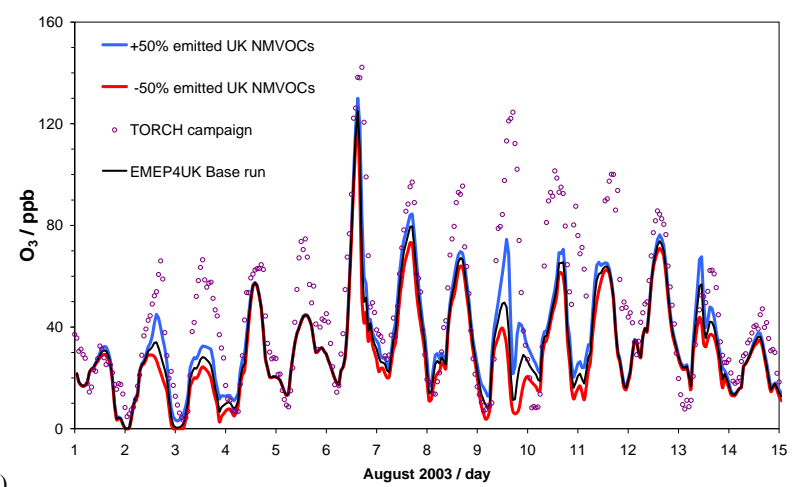

a)

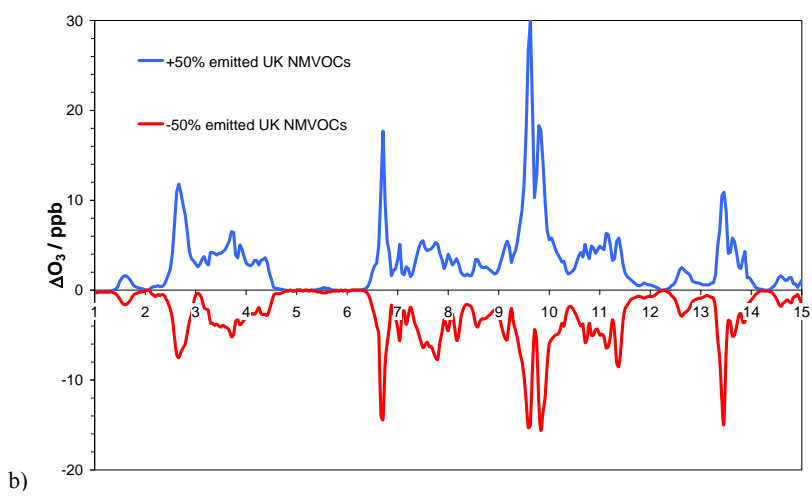

Fig. 9. As for Fig. 8 but for model sensitivity experiments varying the emissions of UK anthropogenic NMVOC $(+50 \%$, blue; $-50 \%$, red).

general both $\mathrm{NO}_{\mathrm{x}}$ and VOC control must be considered together. Such non-linearities are expected from earlier studies (e.g. Sillman et al., 1990; Simpson et al., 1995; BaertschRitter at al., 2004), but quantifying the magnitude of such effects is essential to assess the expected impacts of such policy.

\subsubsection{Biogenic isoprene emissions}

Figure 10 shows the comparison between observed isoprene and model-simulated isoprene at Writtle for the base run and for a $2 \times$ and $5 \times$ increase in UK emissions of biogenic isoprene. The model-simulated isoprene is, in general, in better agreement with observations for the model simulation with double isoprene emissions. In terms of impact on surface ozone (Fig. 11), the models indicates that UK biogenic isoprene emissions contribute up to $\sim 10 \mathrm{ppb}$ ozone on some days in the base run case as compared to the zero isoprene emissions experiment. Doubling UK isoprene emissions enhances surface ozone concentrations by a further $10 \mathrm{ppb}$, and with $5 \times$ emissions the effect is $\sim 5$ times higher (up to $\sim 45 \mathrm{ppb}$ ). An approximately linear dependency of surface ozone to zero, $2 \times$ and $5 \times$ UK biogenic emissions during this period is therefore found with this experiment (Fig. 11).

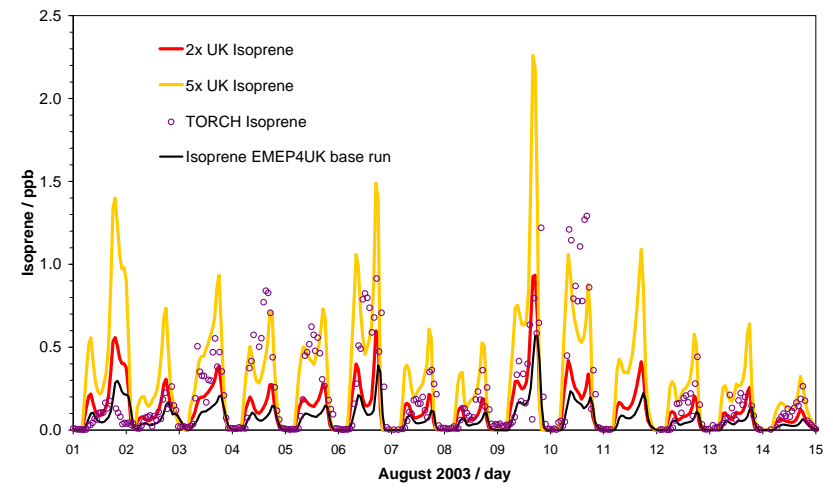

Fig. 10. Time-series of modelled (lines) and measured (circles) hourly surface isoprene (ppb) during August 2003 at Writtle (TORCH).

The maximum change of ozone due to isoprene $(5 \times$ scenario) is $45 \mathrm{ppb}$ which occurred on the 6 August 2003 at 17:00, but when the ozone concentration was at its maximum at 15:00 this difference was $23 \mathrm{ppb}$, which is not the major factor when compared with import on that day (see Sect. 4.2.6). On the 10 August the $5 \times$ scenario fits the observed isoprene concentrations better and the ozone attributable to isoprene emissions is then around $30 \mathrm{ppb}$. Over the whole heat-wave period, it is only on the 10 August that UK isoprene emissions appear to be the dominant cause of elevated ozone concentrations. Taken over an extended period and the whole UK, isoprene emissions had relatively modest effects on simulated UK ozone. However, the modelling suggests that isoprene may play a substantial role for the warmest day at Writtle, when emissions are greatly enhanced.

Unfortunately, emissions of biogenic VOC are notoriously uncertain, with isoprene emissions estimates for the UK exhibiting substantial variability. The emissions estimates of Guenther et al. (1995), Simpson et al. (1999, as used in this work), and Stewart et al. (2003), suggested annual European biogenic isoprene emissions of 110,48 and $8 \mathrm{Gg} \mathrm{Cy}^{-1}$, respectively. There are many reasons for the large differences in inventories and their underpinning emission factors, including limitations in the number of measurements, assumptions concerning extrapolation of emission data and characterisation of the effects of environmental and biogeophysical variables (e.g. temperature, light, soil moisture, canopyeffects, diversity between and among vegetation species). Uncertainties for short time-periods and at specific locations can be expected to be larger than for national averages, and the suggestion of Simpson et al. (1999) that overall biogenic isoprene emissions may be uncertain to within a factor of 3 to 5 may even underestimate the uncertainty of UK emissions during this episode. Moreover, due to the high reactivity of isoprene within this intense photochemical episode, a strong vertical gradient of isoprene is present, as shown in Fig. 12, 


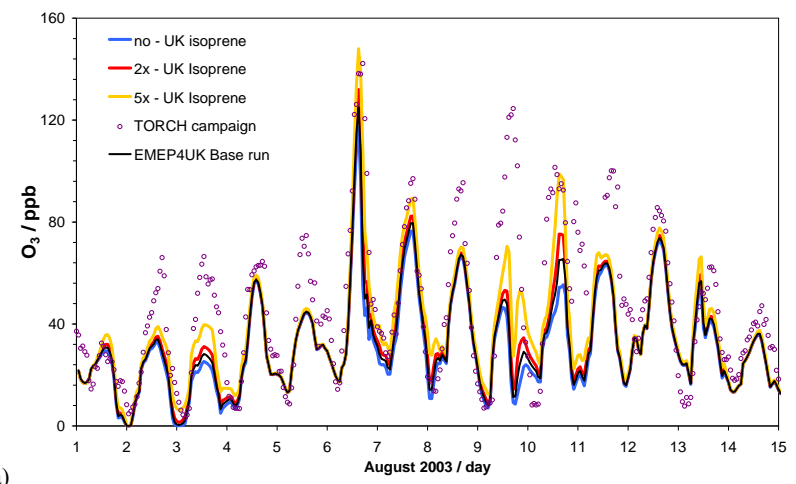

a)

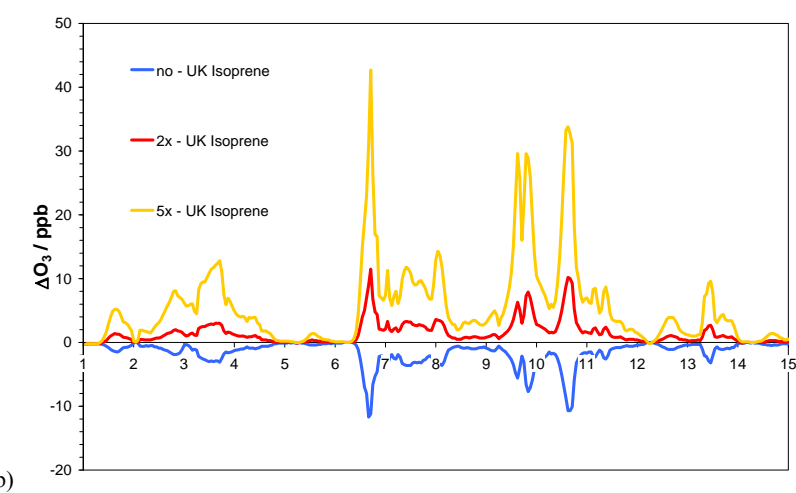

Fig. 11. As for Fig. 8 but for model sensitivity experiments varying the emissions of biogenic isoprene (none, $2 \times, 5 \times$ ).

and the vertical resolution of the model may not be adequate to simulate fully the vertical distribution of isoprene. Despite the above-noted complexities, Fig. 10 shows that the EMEP4UK model was able to simulate isoprene at the Writtle site to within a factor of 3 with respect to observations. It should also be noted that the EMEP4UK model currently does not include estimates of any anthropogenic emissions of isoprene.

The vertical resolution of the model (lowest level thickness ca. $90 \mathrm{~m}$ ) also has strong implications for the comparison of modelled versus observed isoprene concentrations. However, the timescale for mixing in unstable boundary layers is typically much less than the oxidation-lifetime of isoprene to $\mathrm{OH}$ (order $1 \mathrm{~h}$ during daytime), so the model resolution should be adequate for the task. Similar issues apply to $\mathrm{NO}_{\mathrm{x}}$ also, which also has mainly surface sources and chemical loss slower than mixing times.

It should also be noted that the biogenic emission inventory available to this study has a resolution of $50 \times 50 \mathrm{~km}^{2}$, which likely leads to uncertainties in the spatial allocation of isoprene concentrations as applied here. However, isoprene inventories are inherently uncertain, requiring species-level coverage of vegetation which is rarely available (even in the UK), and with different studies suggesting widely different emission factors to be applied (Simpson et al., 1999; Rinne et al., 2009; Stewart et al., 2003).

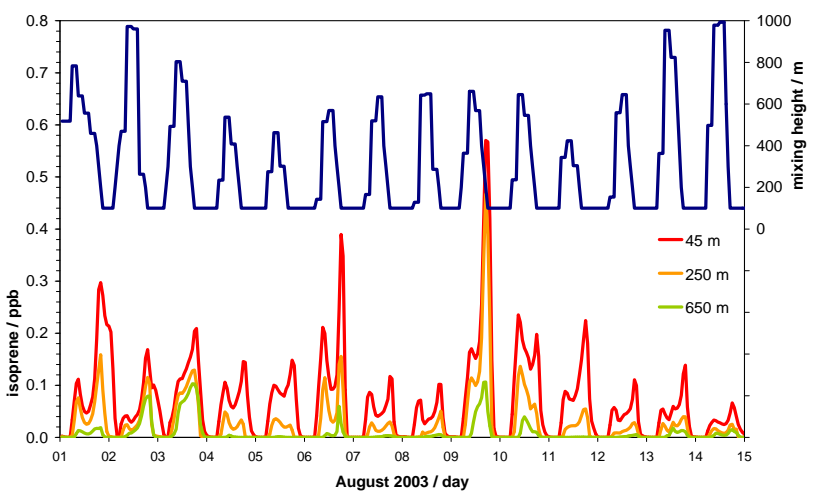

Fig. 12. Time series of modelled hourly isoprene (ppb) for the first, third and fifth level of the EMEP4UK model (mid-level altitudes indicated in the legend) at Writtle for the first 15 days of August 2003 (bottom graph, left hand scale). Modelled boundary layer mixing height (m) is also shown (upper trace, right hand scale).

An interesting feature of surface isoprene was a double peak in the morning and evening, with the latter peak generally higher. This feature (also found by Steinbacher et al., 2005) was present in both observations and simulated isoprene concentrations, as seen in Figs. 10 and 12. $\mathrm{OH}$ is understood to be the cause of the mid-day dip in isoprene concentrations while the afternoon decline in $\mathrm{OH}$ concentration (and hence isoprene loss rate), and increased afternoon temperatures (hence higher isoprene emissions) are the cause of the higher evening peak in isoprene concentrations. Another potentially important contribution to the second peak may be the reduction of the mixing height after sunset (Fig. 12), which will act to limit vertical mixing and dilution. The mixing height and $\mathrm{OH}-$ levels are decreasing at the same time in the evening, thus a combination these two factors may be the cause of the evening isoprene peaks. An interesting day in the period under study here is the 1st August. Here the modelled surface isoprene concentration is still high around midnight. This is likely related to almost complete depletion of ozone in the nocturnal boundary layer in the model (i.e. Fig. 11). When surface ozone is depleted there is no loss of isoprene through the isoprene + ozone reaction or the $\mathrm{NO}_{3}+$ isoprene reaction.

Our results can also be compared to those of Curci et al. (2009), who estimated that BVOC emissions contribute $0-4 \mathrm{ppb}$ towards the maximum daily ozone for the summer (June-July-August) of 2003 in the UK. This is reasonably consistent with our results: we find an EMEP4UK domain average contribution for August of $\sim 1 \mathrm{ppb}$ for the base simulation, and $\sim 3 \mathrm{ppb}$ for the case with $5 \times$ isoprene emissions (Fig. 11).

Finally, it should also be noted that emissions of other BVOC, including monoterpenes but also a whole host of oxygenated species (e.g. Guenther et al., 1995; Seco et al., 2007) are not included in the standard EMEP model. Such 
emissions will affect ozone, often with similar dependencies on temperature to isoprene. However, tests with a research version of the EMEP model (Simpson et al., 2007a) which includes monoterpene emissions, as well as the study of Curci et al. (2009), both suggest that isoprene emissions are a much more important factor than monoterpene emissions for ozone formation in NW Europe, and in any case the effects of monoterpenes should fall within the range of uncertainty we have explored here for isoprene.

The large uncertainties in isoprene emission estimates clearly affect model calculations, and emphasise the need for improved inventories of this important compound as well as of other BVOC compounds.

\subsubsection{Anthropogenic $\mathrm{NO}_{\mathrm{x}}$}

The impact of decreasing UK anthropogenic $\mathrm{NO}_{\mathrm{x}}$ emissions by $10 \%$ and $50 \%$ on modelled surface ozone at Writtle is shown in Fig. 13. This impact varies substantially in both cases across the 15 days in August. As with NMVOC emissions, a decrease in $\mathrm{UK} \mathrm{NO}_{\mathrm{x}}$ emissions affects a few days on which high ozone concentrations were simulated (Fig. 4c). Reducing $\mathrm{NO}_{\mathrm{x}}$ emissions by $10 \%$ and $50 \%$ enhances the surface concentration of ozone by up to $9 \mathrm{ppb}$ and $65 \mathrm{ppb}$, respectively, on 9 August, and up to $4 \mathrm{ppb}$ and $32 \mathrm{ppb}$, respectively, on 2 August, whilst on other days it has less impact (Fig. 13a). On some days both $10 \%$ and $50 \%$ reduction in $\mathrm{NO}_{\mathrm{x}}$ emissions leads to increased ozone, a result of the wellknown titration effect and $\mathrm{NO}_{\mathrm{x}}-\mathrm{VOC}$ relationships in high$\mathrm{NO}_{\mathrm{x}}$ conditions (Sillman et al., 1990; Simpson et al., 1995). The impact on $\mathrm{O}_{3}$ at Writtle acts in the same direction in both cases (10\% and $50 \%$ reduction in $\mathrm{NO}_{\mathrm{x}}$ emissions) for all the days showing little evidence of non-linearity between the $10 \%$ and $50 \%$ experiments.

Figure 14 show maps of the impacts of these $\mathrm{NO}_{\mathrm{x}}$ reductions on changes in daily maximum surface $\mathrm{O}_{3}$ for the 4 and 9 August 2003 across the UK. For most locations across the UK, and on most days, reducing $\mathrm{NO}_{\mathrm{x}}$ emissions leads to higher $\mathrm{O}_{3}$ levels (red colours on Fig. 14). This is especially true for locations downwind of large $\mathrm{NO}_{\mathrm{x}}$ sources (e.g., large urban centres, such as London and Birmingham). This is indicative of the VOC-limited $\mathrm{O}_{3}$ production regime (e.g., see Fig. 3.3a of Royal Society, 2008). In this regime, increases in $\mathrm{NO}_{\mathrm{x}}$ lead to reductions in $\mathrm{O}_{3}$ production. For typical mid-latitude conditions, peak $\mathrm{O}_{3}$ production occurs at around $1 \mathrm{ppb} \mathrm{NO}_{\mathrm{x}}$. This $\mathrm{NO}_{\mathrm{x}}$ level for peak $\mathrm{O}_{3}$ production increases as VOC levels increase. This is particularly relevant during the August 2003 heatwave, as on hotter days, biogenic VOC emissions increase, pushing the position of peak ozone production to higher $\mathrm{NO}_{\mathrm{x}}$ levels, and potentially moving some parts of the UK out of the VOC-limited regime and into the $\mathrm{NO}_{\mathrm{x}}$-limited regime. These regions are the blue regions of Fig. 14 where EMEP4UK simulates less $\mathrm{O}_{3}$ when $\mathrm{NO}_{\mathrm{x}}$ emissions are reduced. These regions tend to be sites more remote from $\mathrm{NO}_{\mathrm{x}}$ emissions (e.g., parts of Wales and

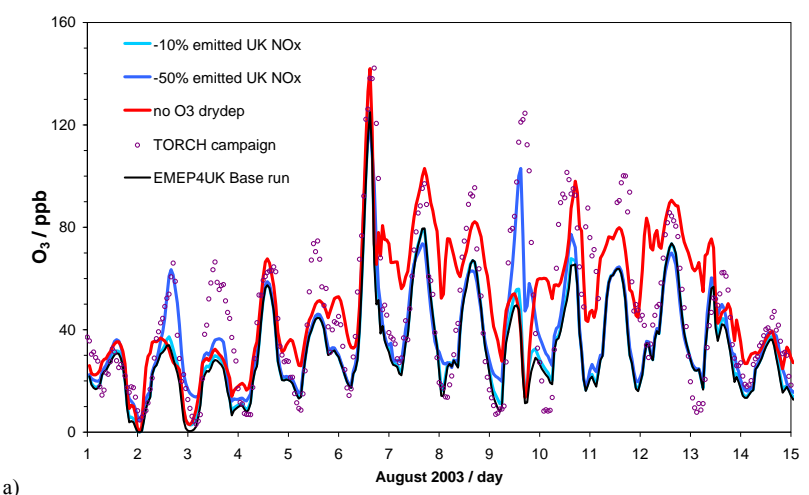

a)

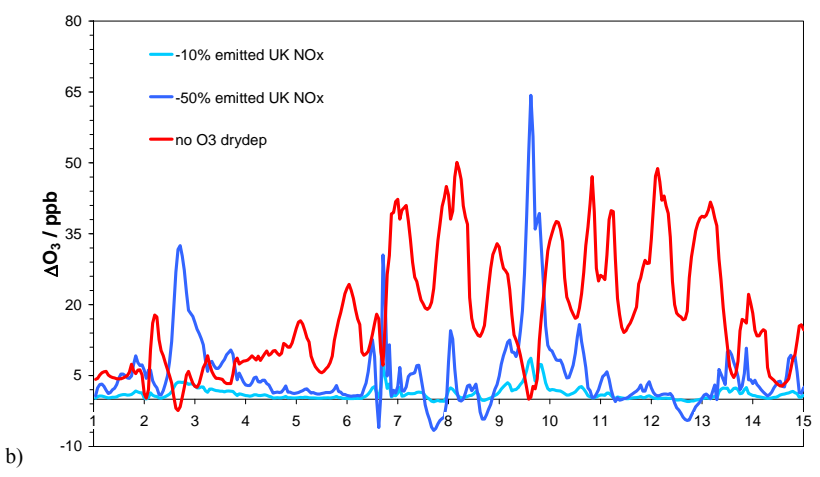

Fig. 13. As for Fig. 8 but for model sensitivity experiments with $-10 \%$ (pale blue) and $-50 \%$ (blue) UK anthropogenic $\mathrm{NO}_{\mathrm{x}}$ emissions and with zero $\mathrm{O}_{3}$ dry deposition (red).

Scotland on 4 August - Fig. 14). These regions of $\mathrm{NO}_{\mathrm{x}}-$ limitation are also slightly more widespread in the $50 \%$ reduction case - this is simply because more regions pass over the peak in the $\mathrm{O}_{3}$ production curve when there is a larger $\mathrm{NO}_{\mathrm{x}}$ reduction. More regions of $\mathrm{NO}_{\mathrm{x}}$-limitation emerge on hotter days during the heatwave (compare 4 and 9 August on Fig. 14 - the 9 was hotter - see Fig. 1); as explained above, these are days with higher VOC levels.

We also show wind speed and wind direction in Fig. 14. The low wind speed and variable wind directions are clearly seen in red region where reducing $\mathrm{NO}_{\mathrm{x}}$ leads to higher $\mathrm{O}_{3}$.

Further results from the $50 \%$ anthropogenic $\mathrm{NO}_{\mathrm{x}}$ emission reduction experiment are shown in Fig. 15. The figure shows hourly modelled values for the whole of August of $\Delta \mathrm{O}_{3} / \Delta \mathrm{NO}_{\mathrm{x}}$ (where $\Delta$ is the change in mixing ratio between the base experiment and the $\mathrm{NO}_{\mathrm{x}}$ reduction experiment), plotted as a function of $\mathrm{NO}_{\mathrm{x}}$ (from the base experiment), for three sites (Wicken Fen, Writtle, and London Eltham). The three sites broadly represent the gradation from relatively rural (Wicken Fen), with $\sim 0.5-5 \mathrm{ppb} \mathrm{NO}_{\mathrm{x}}$, to urban (London Eltham), with $\sim 5-50 \mathrm{ppb}$. Writtle is generally less polluted than London, but has similar upper values, when directly within the London plume $\left(\mathrm{NO}_{\mathrm{x}} \sim 2-50 \mathrm{ppb}\right)$. At all sites (and especially in London), for most of the time, 


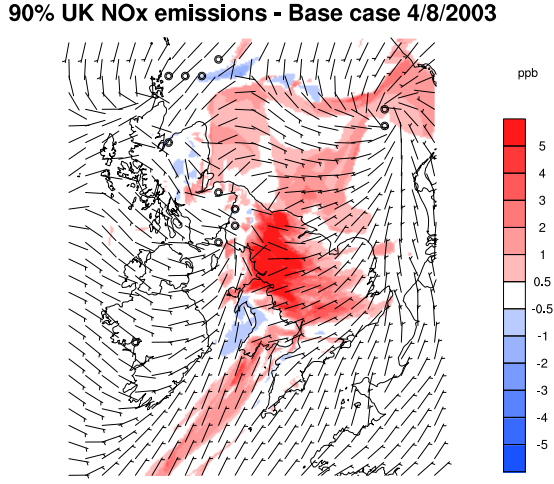

90\% UK NOx emissions - Base case 9/8/2003

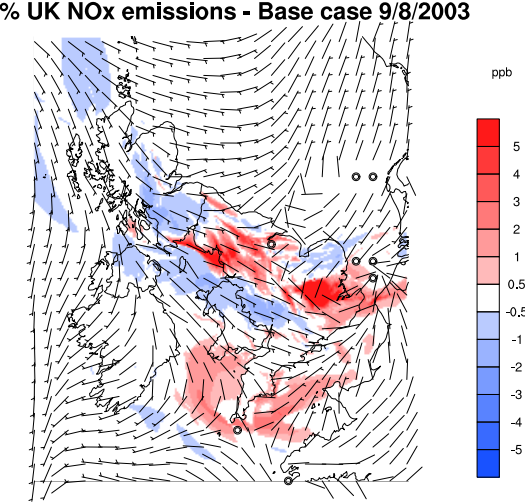

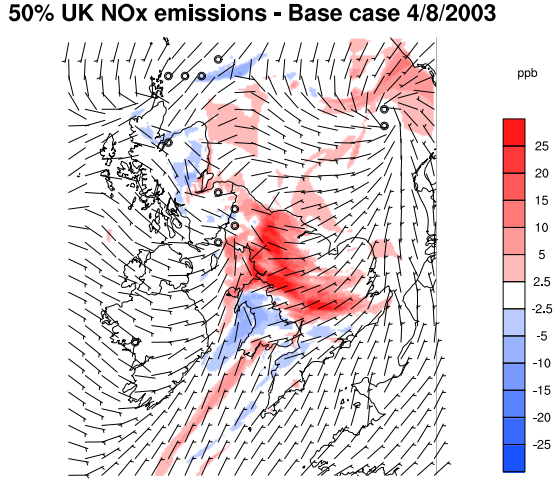

$50 \%$ UK NOx emissions - Base case $9 / 8 / 2003$

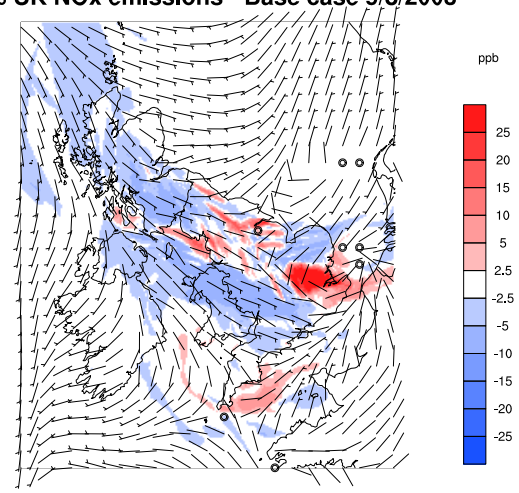

Fig. 14. Change in simulated surface daily maximum ozone (ppb) relative to the base case scenario for the sensitivity experiment with $10 \%$ (left) and $50 \%$ (right) reduction of the UK anthropogenic $\mathrm{NO}_{\mathrm{x}}$ emissions, for two days, 4 (upper panels) and 9 August (lower panels). The 12:00 $10 \mathrm{~m}$ wind is also shown.

ozone declines as $\mathrm{NO}_{\mathrm{x}}$ increases (i.e. most $\Delta \mathrm{O}_{3} / \Delta \mathrm{NO}_{\mathrm{x}}$ values are negative), indicative of a VOC-limited regime. At times of lower background $\mathrm{NO}_{\mathrm{x}}$, additional $\mathrm{NO}_{\mathrm{x}}$ sometimes leads to increases in $\mathrm{O}_{3}$ - this is seen most often at the more rural site - indicating a $\mathrm{NO}_{\mathrm{x}}$-limited regime. There is not a single value for background $\mathrm{NO}_{\mathrm{x}}$ where the switch from $\mathrm{NO}_{\mathrm{x}}$-limited to VOC-limited occurs (this will be a function of several other variables, e.g. VOC levels), but the regime is clearly VOC-limited above $\sim 8 \mathrm{ppb} \mathrm{NO}_{\mathrm{x}}$, and $\mathrm{NO}_{\mathrm{x}}$-limited below $\sim 0.5 \mathrm{ppb} \mathrm{NO}_{\mathrm{x}}$. This is broadly consistent with the schematic figure presented in the Royal Society report discussed above.

These sensitivity tests further support the conclusion that the deviations between modelled and observed $\mathrm{O}_{3}$ were particularly related to uncertainties in local patterns of calculated $\mathrm{NO}_{\mathrm{x}}$ concentrations, which may be related to local uncertainties in the $\mathrm{NO}_{\mathrm{x}}$ emission data. Figure 14 highlights the area affected by the London plume. The location of Writtle is on the edge of the London plume and is therefore highly sensitive to small errors in modelled location of the plume. This is illustrated by the fact that on 9 August the model performed well for the two sites Wicken Fen and London Eltham, which were well outside and inside the London $\mathrm{NO}_{\mathrm{x}}$ plume, respectively. The model does not agree well with observed $\mathrm{NO}_{2}$ at Writtle for the first 9 days of August, but shows better agreement for the remaining days included in this study (Fig. 16).

In general the EMEP4UK model captures the concentration of $\mathrm{NO}_{2}$ quite well (fine-scale models typically have trouble simulating $\mathrm{NO}_{2}$ ), and with a reasonable diurnal variation on most days. Nevertheless, significant over-predictions are seen on the nights of 2, 3, 9 and 10 August. The discrepancy between modelled and observed $\mathrm{NO}_{2}$ is consistent with the larger standard deviation of the observed averaged $\mathrm{NO}_{2}$ concentrations from the high frequency observations during the first week compared with the second week of August (data not shown). Large standard deviations imply the existence of fast small-scale variations of concentration due to local factors which are much more difficult to represent in models. Other studies (e.g., Baertsch-Ritter et al., 2003) also highlight difficulties in simulating urban $\mathrm{NO}_{\mathrm{x}}$ plumes as a result of emission uncertainties. 


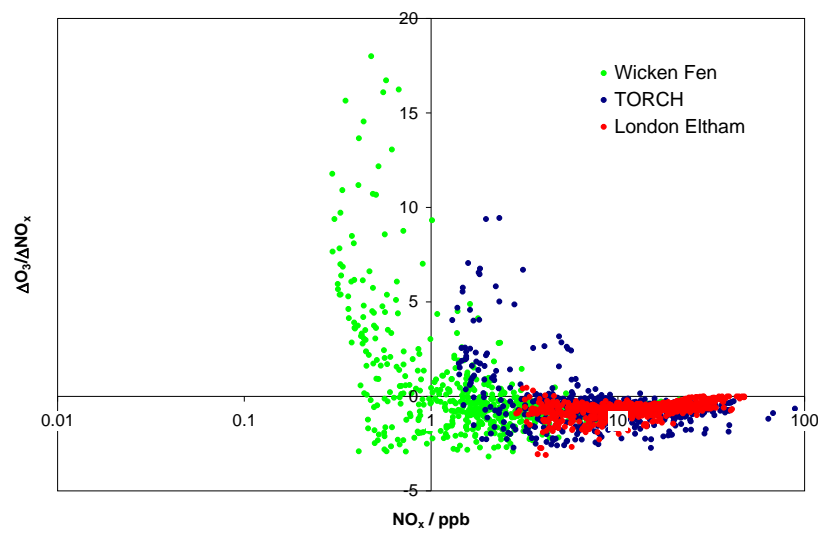

Fig. 15. Hourly modelled values at three sites (Wicken Fen - green; Writtle - blue; and London Eltham - red) for the whole of August of the ratio $\Delta \mathrm{O}_{3} / \Delta \mathrm{NO}_{\mathrm{x}}$ (where $\Delta$ is the change in mixing ratio between the base experiment and the $50 \% \mathrm{NO}_{\mathrm{X}}$ reduction experiment), plotted as a function of base experiment $\mathrm{NO}_{\mathrm{X}}$.

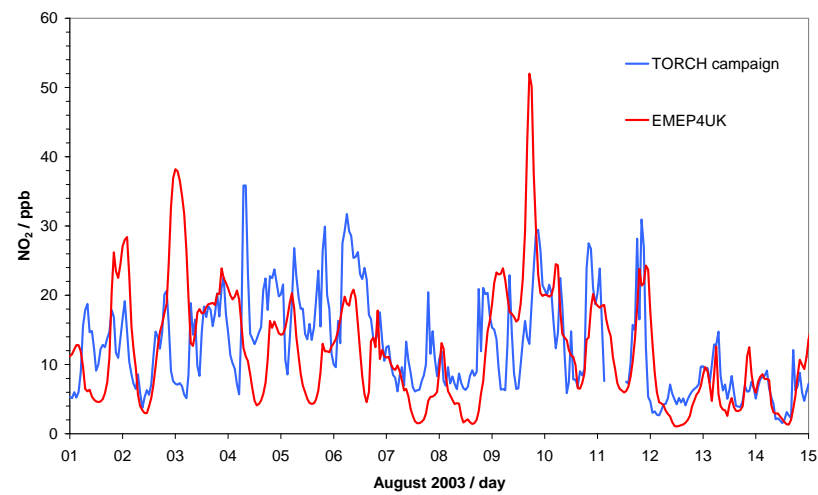

Fig. 16. Hourly time-series of modelled (red) and observed (blue) surface $\mathrm{NO}_{2}$ (ppb) during August 2003 at Writtle.

\subsubsection{Ozone dry deposition}

Dry deposition of ozone is a major factor controlling the magnitude of surface ozone concentrations, and during the extreme conditions of August 2003 there is a possibility that uptake to vegetation was severely restricted, as stomatal deposition is a strong function of temperature, humidity, and sunlight (Emberson et al., 2001; Simpson et al., 2007b). The impact of switching off UK ozone dry deposition (both stomatal and non stomatal) is also shown in Fig. 13. This model change had a comparatively large impact on surface ozone throughout the simulation period, particularly at night time when surface ozone increases up to $50 \mathrm{ppb}$.

Suppressing dry deposition in the model generally increased surface ozone, as expected, although there were two points on 2 August when ozone was reduced in the late afternoon/early evening (Fig. 13). This must have been due to the earlier, enhanced levels of $\mathrm{O}_{3}$ influencing the abun-
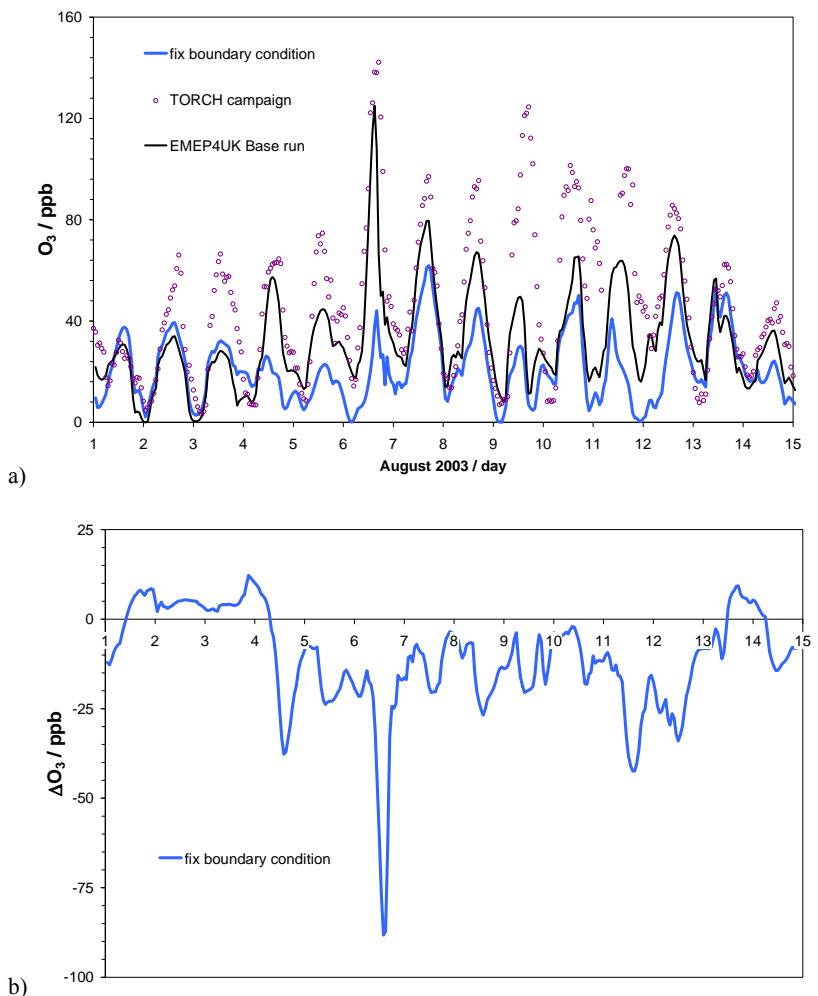

Fig. 17. As for Fig. 8, but for the model sensitivity experiment with fixed (climatological) $\mathrm{O}_{3}$ at the boundary of the EMEP4UK inner domain.

dance of $\mathrm{O}_{3}$ precursors to such an extent that although deposition was switched off, $\mathrm{O}_{3}$ levels fell below those in the control simulation. Our results show clearly that in general, turning off ozone dry deposition increases modelled ozone concentrations. In the case of the anomalous two-hour period, $\mathrm{NO}_{2}$ was also overestimated compared with the measurements. This suggests a temporal interaction between $\mathrm{O}_{3}$ dry deposition and NO concentrations may have occurred, whereby previous higher $\mathrm{O}_{3}$ concentrations (as a result of no model dry deposition), had depleted the modelled NO levels, thereby briefly limiting the potential for $\mathrm{O}_{3}$ formation.

Vautard et al. (2005) suggest that due to the exceptionally hot weather of August 2003 over Europe, dry deposition calculations in their model needed to be modified to reduce dry deposition of ozone. The present study however retains the unmodified dry deposition calculation for the full year simulation of 2003 suggesting that for the UK the parameterisation used in the EMEP model for dry deposition is, in general, adequate for the range of temperature and extreme weather modelled here. Nevertheless, we do find on some specific occasions (e.g., night of 10/11 August) switching off deposition improves the comparison with observations. 

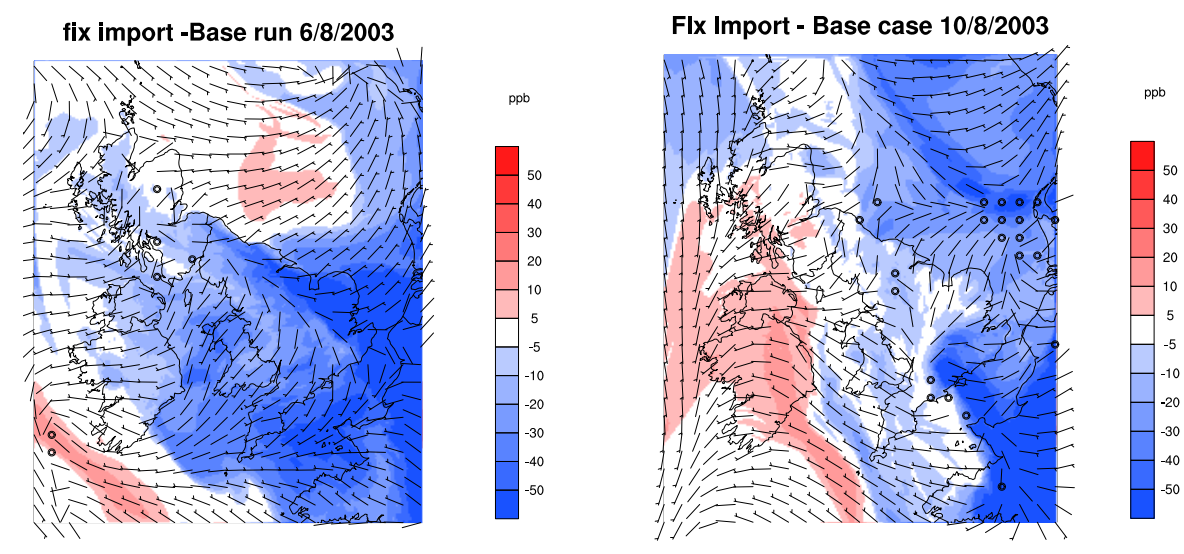

Fig. 18. Change in simulated surface daily maximum ozone (ppb) relative to the base case scenario for the sensitivity experiment with fixed (climatological) boundary condition for $\mathrm{O}_{3}$, for 6 and 10 August 2003. The 12:00 $10 \mathrm{~m}$ wind is also shown.

\subsubsection{UK import}

In the final sensitivity experiment, the ozone boundary conditions for the inner domain $\left(5 \times 5 \mathrm{~km}^{2}\right.$ region) of the EMEP4UK model were fixed to climatological values (32 ppb - Logan, 1999) for the whole month, rather than using output from the larger scale $50 \times 50 \mathrm{~km}^{2}$ runs. The results of this sensitivity test (Fig. 17) show that in August 2003 surface ozone concentrations were strongly influenced by import on most days, especially in SE England (Fig. 18). Import contributed up to $85 \mathrm{ppb}$. For example, most of the ozone present at Writtle on the 6 August was generated and imported from outside the EMEP4UK inner domain.

Correct boundary conditions are very important to accurately calculate UK surface ozone and previous work has demonstrated that European transport and trans-Atlantic transport are well simulated by the EMEP model (e.g. Jonson et al., 2006). Figures 17 and 18 show that the import of ozone from outside the UK was typically the most important factor contributing to the very high surface ozone in SE England during August 2003. Import is important on different days at different locations (Fig. 18). This is evident for the 6 and 10 August (Fig. 18) when localised incursions of European-emitted precursors and/or ozone itself were present. This agrees with Solberg et al. (2008), who reported that the higher values of ozone observed over SE England were often the result of import from the continent. However, one of the conclusions in Solberg et al. (2008) was that Portuguese forest fires were a possible cause for the unusually high surface ozone over Europe. The EMEP4UK model was able to simulate high surface ozone without emissions from forest fires, further development of the EMEP model to include forest fire emissions should be undertaken in order to properly assess their impact on ozone over the UK.
Overall, however, it has been shown that, during the TORCH campaign at Writtle, the high level of ozone observed was not created within the model domain of the British Isles, but imported from continental Europe. Figure 18 highlights this clearly on the 6 of August where an incursion of European ozone was present in SE England. The simulations of Solberg et al. (2008) showed a cluster of high ozone concentrations ( $>90 \mathrm{ppb}$ ) near the border between France and Germany on this date. The implication is that ozone produced in this region was thereafter advected over the UK. High resolution modelling is also critical as this type of incursion may influence a small area $\left(<100 \mathrm{~km}^{2}\right)$ as can be seen in Fig. 18 for the 10 August.

\section{Summary and conclusions}

For the first time a derivative of the EMEP Unified model (EMEP4UK) has been successfully applied to the UK at an enhanced horizontal resolution of $5 \times 5 \mathrm{~km}^{2}$ to simulate surface ozone, and been driven by the WRF model instead of the HIRLAM model used to drive the Unified model. Particular attention has been given to the site at Writtle, where the TORCH campaign made extensive atmospheric measurements, and at two nearby rural and urban background sites.

Modelled meteorology shows some biases compared to observations (Figs. 1 and 2). Daily maximum surface temperatures during the heat-wave are underestimated by up to $5 \mathrm{~K}$ at some sites, but averaged across all UK sites, average surface temperature model bias is $-1.5 \mathrm{~K}$. Most diurnal and day-to-day meteorological variability is well captured. Seasonal, day-to-day and diurnal variations in ozone are also well simulated (Figs. 3 and 4). Model performance at Writtle, the site with a large suite of campaign measurements during August 2003, is worse than at neighbouring long-term monitoring sites (Figs. 1, 4 and 5). Model results indicate that Writtle is a relatively difficult site to simulate, because 
it is intermittently exposed to the plume of pollution emanating from greater London and its proximity to the coast. Both these factors contribute to steep spatial gradients in meteorology and air pollutants near the site (Figs. 6 and 7). Nevertheless, model performance is sufficiently good for us to use model results for the site, together with the detailed campaign measurements, to investigate the origins of ozone during the heat-wave.

A series of sensitivity experiments were performed with the model, repeatedly simulating the heat-wave period (Table 1). In each experiment an individual model parameter/input was varied across the EMEP4UK domain, in order to isolate and quantify its influence on ozone. Uniformly increasing surface temperature by $5 \mathrm{~K}$ led to increases in ozone at Writtle of up to $9 \mathrm{ppb}$ on certain days; decreasing temperature by the same amount induced similar magnitude ozone reductions (Fig. 8).

The main influence of temperature on ozone is via biogenic isoprene; doubling isoprene emissions produced a similar response to increasing temperature by $5 \mathrm{~K}$ (Fig. 11). Removing isoprene emissions, or multiplying them by five, induced ozone responses that indicate a broadly linear response of ozone to the magnitude of isoprene emissions on specific days (Fig. 11). Isoprene concentrations at Writtle show significant day-to-day variability, and this is partly captured by the model (Fig. 10). Overall during the heat-wave, we found that doubling baseline isoprene emissions produced the best fit to observations, although on some days the $5 \times$ experiment was best.

Days with the highest sensitivity of ozone to isoprene (6, 9 and 10 August) were days with high isoprene levels, although other days with similarly high isoprene levels (4 and 5 August) showed much lower sensitivity. This sensitivity is a function of coincident $\mathrm{NO}_{\mathrm{x}}$ levels; relative amounts of $\mathrm{NO}_{\mathrm{x}}$ and VOC determine whether ozone production is $\mathrm{NO}_{\mathrm{x}}-$ limited or VOC-limited. These changes in ozone production regime are clearly shown with results from sensitivity experiments that reduced anthropogenic $\mathrm{NO}_{\mathrm{x}}$ emissions. Figure 14 shows the influence of these $\mathrm{NO}_{\mathrm{x}}$ reductions on surface ozone across the model domain for 4 and 9 August. On the 4th, winds at Writtle were from the East, and the ozone production regime is not strongly VOC-limited, hence the low sensitivity of ozone to isoprene emissions on this day. In contrast on the 9th, winds are lighter, Writtle is within the London plume, the ozone production regime is VOC-limited, and consequently there is a higher sensitivity of ozone to isoprene emissions. The ozone production regime at Writtle is generally VOC-limited, like London, but occasionally is $\mathrm{NO}_{\mathrm{x}}$-limited, like the more rural Wicken Fen site (Fig. 15). Experiments varying anthropogenic NMVOC emissions also show strong day-to-day variations in the sensitivity of ozone at Writtle (Fig. 9), again illustrating the importance of the prevailing ozone production regime.
Switching off the biophysical process of dry deposition across the UK increases ozone at Writtle by up to $50 \mathrm{ppb}$, and improves the fit to observed ozone on some days (Fig. 13). The influence on ozone on most heat-wave days is $\sim 20$ $35 \mathrm{ppb}$, although on some days there is much less impact (e.g. 9 August).

Setting ozone at the model boundaries to a climatological value, rather than allowing it to vary, shows that import of ozone from outside the EMEP4UK domain typically contributes $\sim 15-20 \mathrm{ppb}$ to ozone levels at Writtle, but up to $85 \mathrm{ppb}$ on 6 August (Figs. 17 and 18).

In summary, we find that multiple important influences contributed to the elevated ozone over SE England during the August 2003 heat-wave. Our simulations indicate that different processes dominated at different times, with local biogenic and anthropogenic emissions important on some days, whilst import from Europe and suppression of dry deposition were important on other days. All these processes need to be simulated accurately in order to fully understand the episode.

Acknowledgements. This work is supported jointly by the UK Department for Environment Food and Rural Affairs (Defra), the Centre for Ecology and Hydrology (CEH), the Natural Environment Research Council (NERC) under its Environment and Health Programme (Grant NE/E008593/1), the EMEP programme under the UNECE LRTAP Convention, and the Norwegian Meteorological Institute (Met.No), and provides a contribution to the work of the NitroEurope Integrated Project (Verification Component) funded by the European Commission. We gratefully acknowledge travel support from the COST 729 action and the European Science Foundation NinE programme.

Edited by: A. S. H. Prevot

\section{References}

Andersson-Skold, Y. and Simpson, D.: Comparison of the chemical schemes of the EMEP MSC-W and IVL photochemical trajectory models, Atmos. Environ., 33, 1111-1129, 1999.

Andreani-Aksoyoglu, S., Keller, J., Prevot, A. S. H., Baltensperger, U., and Flemming, J.: Secondary aerosols in Switzerland and northern Italy: Modeling and sensitivity studies for summer 2003, J. Geophys. Res.-Atmos., 113, D06303, doi:10.1029/2007JD009053, 2008.

Baertsch-Ritter, N., Keller, J., Dommen, J., and Prevot, A. S. H.: Effects of various meteorological conditions and spatial emissionresolutions on the ozone concentration and ROG/NO $\mathrm{Xim}$ itationin the Milan area (I), Atmos. Chem. Phys., 4, 423-438, doi:10.5194/acp-4-423-2004, 2004.

Baertsch-Ritter, N., Prevot, A. S. H., Dommen, J., AndreaniAksoyoglu, S., and Keller, J.: Model study with uam-v in the milan area (i) during PIPAPO: Simulations with changed emissions compared to ground and airborne measurements, Atmos. Environ., 37, 4133-4147, 2003.

Berge, E. and Jakobsen, H. A.: A regional scale multi-layer model for the calculation of long term transport and deposition of air pollution in Europe, Tellus, 50, 205-223, 1998. 
Chaxel, E. and Chollet, J. P.: Ozone production from Grenoble city during the August 2003 heat wave, Atmos. Environ., 43, 47844792, 2009.

Cox, R., Eggleton, A., Derwent, R., Lovelock, J., and Pack, D.: Long range transport of photochemical ozone in North-Western Europe, Nature, 255, 118-121, 1975

Curci, G., Beekmann, M., Vautard, R., Smiatek, G., Steinbrecher, R., Theloke, J., and Friedrich, R.: Modelling study of the impact of isoprene and terpene biogenic emissions on European ozone levels, Atmos. Environ., 43, 1444-1455, 2009.

Dore, C. J., Murrells, T. P., Passant, N. R., Hobson, M. M., Thistlethwaite, G., Wagner, A., Li, Y., Bush, T., King, K. R., Norris, J., Coleman, P. J., Walker, C., Stewart, R. A., Tsagatakis, I., Conolly, C., Brophy, N. C. J., and Hann, M. R.: UK Emissions of Air Pollutants 1970 to 2006, AEA Energy \& Environment, Harwell, Oxfordshire, 2008.

Emberson, L., Ashmore, M., Simpson, D., Tuovinen, J.-P., and Cambridge, H.: Modelling and mapping ozone deposition in Europe, Water Air Soil Pollut., 130, 577-582, 2001.

Fagerli, H., Simpson, D., and Tsyro, S.: Transboundary acidification, eutrophication and ground level ozone in Europe, EMEP Status Report 1/2004, Unified EMEP model: Updates, The Norwegian Meteorological Institute, Oslo, Norway, 11-18, 2004.

Gardner, R. M., Adams, K., Cook, T., Deidewig, F., Ernedal, S., Falk, R., Fleuti, E., Herms, E., Johnson, C. E., Lecht, M., Lee, D. S., Leech, M., Lister, D., Masse, B., Metcalfe, M., Newton, P., Schmitt, A., Vandenbergh, C., and VanDrimmelen, R.: The ANCAT/EC global inventory of $\mathrm{NO}_{\mathrm{x}}$ emissions from aircraft, Atmos. Environ., 31, 1751-1766, 1997.

Guicherit, R. and van Dop, H.: Photochemical production of ozone in Western Europe and its relation to meteorology 1971-1975, Atmos. Environ., 11, 145-155, 1977

Guenther, A. B., Zimmerman, P. R., Harley, P. C., Monson, R. K. and Fall, R.: Isoprene and monoterpene emission rate variability: model evaluations and sensitivity analyses, J. Geophys. Res., 98(D7), 12609-12617, 1993.

Guenther, A., Hewitt, C., Erickson, D., Fall, R., Geron, C., Graedel, T., Harley, P., Klinger, L., Lerdau, M., McKay, W., Pierce, T., Scholes, R., Steinbrecher, R., Tallamraju, R., Taylor, J., and Zimmerman, P.: A global model of natural volatile organic compound emissions, J. Geophys. Res., 100(D5), 8873-8892, 1995.

Hellsten, S, Dragosits, U., Place, C. J, Vieno, M, Dore, A. J, Misselbrook, T. H., Tang Y. S., and Sutton, M. A.: Modelling the spatial distribution of ammonia emissions in the UK, Environ. Pollut., 154, 370-379, 2008.

Jenkin, M. E., Davies, T. J., and Stedman, J. R, The origin and day-of-week dependence of photochemical ozone episodes in the UK, Atmos. Environ., 36, 999-1012, 2002

Jonson, J. E., Simpson, D., Fagerli, H., and Solberg, S.: Can we explain the trends in European ozone levels?, Atmos. Chem. Phys., 6, 51-66, doi:10.5194/acp-6-51-2006, 2006.

Jonson J. E., Tarrason L., Wind P., Gauss M., Valiyaveetil S. S., Tsyro S., Klein H., Isaksen S. A. I., and Benedictow A.: First evaluation of the global EMEP model and comparison with the global OsloCTM2 model. EMEP/MSC-W Technical Report 2/07. Norwegian Meteorological Institute, Blindern. Norway, 2007.

Jonson, J. E. and Travnikov, O. (eds.): Development of the EMEP global modeling framework: Progress report; Joint MSC-
W/MSC-E Report. EMEP/MSC-W Technical Report 1/2010. Norwegian Meteorological Institute, Blindern, Norway, 2010.

Köhler, I., Sausen, R., and Klenner, G.: $\mathrm{NO}_{\mathrm{x}}$ production from lightning, in: The impact of $\mathrm{NO}_{\mathrm{x}}$ emissions from aircraft upon the atmosphere at flight altitudes $8-15 \mathrm{~km}$ (AERONOX), edited by: Schumann, U., final report to the Commission of the European Communities, Deutch Luft und Raumfart, Oberpfaffenhofen, Germany, 1995.

Lee, J. D., Lewis, A. C., Monks, P. S., Jacob, M., Hamilton, J. F., Hopkins, J. R., Watson, N. M., Saxton, J. E., Ennis, C., Carpenter, L. J., Carslaw, N., Fleming, Z., Bandy, B. J., Oram, D. E., Penkett, S. A., Slemr, J., Norton, E., Rickard, A. R., Whalley, L. K., Heard, D. E., Bloss, W. J., Gravestock, T., Smith, S. C., Stanton, J., Pilling, M. J., and Jenkin, M. E.: Ozone photochemistry and elevated isoprene during the UK heatwave of August 2003, Atmos. Environ., 40, 7598-7613, 2006.

Logan, J. A.: An analysis of ozonesonde data for the troposhere: Recommendations for testing 3-d models and development of a gridded climatology for troposheric ozone, J. Geophys. Res., 104(D13), 16115-16149, 1999.

Metzger, S., Dentener, F., Pandis, S., and Lelieveld, J.: Gas/aerosol partitioning: 1. A computationally efficient model, J. Geophys. Res.-Atmos., 107(D16), 4312, doi:10.1029/2001JD001102, 2002.

Ordóñez, C., Mathis, H., Furger, M., Henne, S., Hüglin, C., Staehelin, J., and Prévôt, A. S. H.: Changes of daily surface ozone maxima in Switzerland in all seasons from 1992 to 2002 and discussion of summer 2003, Atmos. Chem. Phys., 5, 1187-1203, doi:10.5194/acp-5-1187-2005, 2005.

Rinne, J., Back, J., and Hakola, H.: Biogenic volatile organic compound emissions from the eurasian taiga: Current knowledge and future directions, Boreal Environ. Res., 14, 807-826, 2009.

Royal Society: Ground-level ozone in the 21 st century: future trends, impacts and policy implications, RS Policy document 15/08, London, 2008.

Schär, C. and Jendritzky, G.: Climate change: Hot news from summer 2003, Nature, 432, 559-560, 2004.

Seco, R., Penuelas, J., and Filella, I.,: Short-chain oxygenated VOCs: Emission and uptake by plants and atmospheric sources, sinks, and concentrations, Atmos. Environ., 41, 2477-2499, 2007

Sillman, S. and Samson, F. J.: Impact of temperature on oxidant photochemistry in urban, polluted rural and remote environments, J. Geophys. Res.-Atmos., 100, 11497-11508, 1995.

Sillman, S.; Logan, J., and Wofsy, S.: The sensitivity of ozone to nitrogen oxides and hydrocarbons in regional ozone episodes, J. Geophys. Res.-Atmos., 95, 1837-1851, 1990

Simpson, D. Biogenic emissions in Europe 2: Implications for ozone control strategies, J. Geophys. Res.-Atmos., 100, 2289122906, 1995

Simpson, D., Winiwarter, W., Borjesson, G., Cinderby, S., Ferreiro, A., Guenther, A., Hewitt, C. N., Janson, R., Khalil, M. A. K., Owen, S., Pierce, T. E., Puxbaum, H., Shearer, M., Skiba, U., Steinbrecher, R., Tarrason, L., and Oquist, M. G.: Inventorying emissions from nature in Europe, J. Geophys. Res.-Atmos., 104(D7), 8113-8152, 1999.

Simpson, D., Fagerli, H., Jonson, J. E., Tsyro, S., Wind, P., and Tuovinen, J. P.: Transboundary Acidification, Eutrofication and Ground Level Ozone in Europe. Part 1. Unified EMEP Model 
Description. EMEP/MSC-W Report 1/03, Norwegian Meteorological Institute, Blindern, Norway, 2003a.

Simpson, D., Tuovinen, J.-P., Emberson, L. D., and Ashmore, M. R.: Characteristics of an ozone deposition module II: Sensitivity analysis, Water Air Soil Pollut., 143, 123-137, 2003 b.

Simpson, D., Yttri, K., Klimont, Z., Kupiainen, K., Caseiro, A., Gelencsér, A., Pio, C., and Legrand, M.: Modeling Carbonaceous Aerosol over Europe. Analysis of the CARBOSOL and EMEP EC/OC campaigns, J. Geophys. Res.-Atmos., 112, D23S14, doi:10.1029/2006JD008158, 2007a.

Simpson, D., Emberson, L., Ashmore, M., and Tuovinen, J.: A comparison of two different approaches for mapping potential ozone damage to vegetation. A model study, Environ. Pollut., 146, 715-725, doi:10.1016/j.envpol.2006.04.013, 2007b.

Solberg, S., Hov, O., Sovde, A., Isaksen, I. S. A., Coddeville, P., De Backer, H., Forster, C., Orsolini, Y., and Uhse, K.: European surface ozone in the extreme summer 2003, J. Geophys. Res.Atmos., 113, D07307, doi:10.1029/2007JD009098, 2008.

Stedman, J. R.: The predicted number of air pollution related deaths in the UK during the August 2003 heatwave, Atmos. Environ., 38, 1087-1090, 2004.

Steinbacher, M., Dommen, J., Ordonez, C., Reimann, S., Gruebler, F., Staehelin, J., Andreani-Aksoyoglu, S., and Prevot, A. S. H.: Volatile organic compounds in the Po basin. Part B: Biogenic VOCs, J. Atmos. Chem., 51, 293-315, 2005.

Stewart, H. E., Hewitt, C. N., Bunce, R. G. H., Steinbrecher, R., Smiatek, G., and Schoenemeyer, T.: A highly spatially and temporally resolved inventory for biogenic isoprene and monoterpene emissions: Model description and application to Great Britain, J. Geophys. Res.-Atmos., 108, 4644, doi:10.1029/2002JD002694, 2003.
Tarrason, L., Turner, S., and Floisand, I.: Estimation of Seasonal Dimethyl Sulfide Fluxes over the North-Atlantic Ocean and Their Contribution to European Pollution Levels, J. Geophys. Res.-Atmos., 100, 11623-11639, 1995.

Tressol, M., Ordonez, C., Zbinden, R., Brioude, J., Thouret, V., Mari, C., Nedelec, P., Cammas, J.-P., Smit, H., Patz, H.-W., and Volz-Thomas, A.: Air pollution during the 2003 European heat wave as seen by MOZAIC airliners, Atmos. Chem. Phys., 8, 2133-2150, doi:10.5194/acp-8-2133-2008, 2008.

Trigo, R. M., Garcia-Herrera, R., Diaz, J., Trigo, I. F., and Valente, M. A.: How exceptional was the early August 2003 heatwave in France?, Geophys. Res. Lett., 32, L10701, doi:10.1029/2005GL022410, 2005.

Vautard, R., Honore, C., Beekmann, M., and Rouil, L.: Simulation of ozone during the August 2003 heat wave and emission control scenarios, Atmos. Environ., 39, 2957-2967, 2005.

Vieno, M., Dore, A. J., Wind, P., Di Marco, C., Nemitz, E., Phillips, G., Tarrason, L., and Sutton, M. A.: Application of the EMEP Unified Model to the UK with a Horizontal Resolution of $5 \times 5 \mathrm{~km}^{2}$, Atmospheric Ammonia - Detecting Emission Changes and Environmental Impacts, edited by: Sutton, M. A., Reid, S., and Baker, S. M. H., Springer, 367-372, 2009. 